\title{
The cancer epigenome-components and functional correlates
}

\author{
Angela H. Ting, ${ }^{1}$ Kelly M. McGarvey, ${ }^{1,2}$ and Stephen B. Baylin ${ }^{1,2,3}$ \\ ${ }^{1}$ The Sidney Kimmel Comprehensive Cancer Center at Johns Hopkins, Baltimore, Maryland 21231, USA; ${ }^{2}$ The Graduate \\ Program in Cellular and Molecular Medicine, The Johns Hopkins University School of Medicine, \\ Baltimore, Maryland 21205, USA
}

It is increasingly apparent that cancer development not only depends on genetic alterations but on an abnormal cellular memory, or epigenetic changes, which convey heritable gene expression patterns critical for neoplastic initiation and progression. These aberrant epigenetic mechanisms are manifest in both global changes in chromatin packaging and in localized gene promoter changes that influence the transcription of genes important to the cancer process. An exciting emerging theme is that an understanding of stem cell chromatin control of gene expression, including relationships between histone modifications and DNA methylation, may hold a key to understanding the origins of cancer epigenetic changes. This possibility, coupled with the reversible nature of epigenetics, has enormous significance for the prevention and control of cancer.

The fact that virtually all human cancer types have epigenetic abnormalities that collaborate with genetic changes to drive progressive stages of tumor evolution has been the subject of multiple recent reviews (Jones and Baylin 2002; Herman and Baylin 2003; Feinberg and Tycko 2004; Lund and van Lohuizen 2004b; Baylin and Ohm 2006; Feinberg et al. 2006). This recognition intersects with the explosion of knowledge about the role of chromatin assembly and modification in the control of gene expression patterns (Strahl and Allis 2000; Jenuwein and Allis 2001; Bannister et al. 2002; Briggs et al. 2002; Lachner and Jenuwein 2002) to present a rich opportunity for understanding how tumor-related epigenetic changes are initiated and maintained. In mammalian cells, for proper packaging of DNA to ensure the balance between transcriptional activity and repression, there is a dynamic regulation of DNA cytosine methylation at CpG sites, nucleosome remodeling, and a series of deacetylation, methylation, and other modifications at key histone amino acid residues (Bestor 1998; Bird and Wolffe 1999; Strahl and Allis 2000; Jenuwein and Allis 2001; Bannister et al. 2002; Bird 2002; Briggs et al. 2002;

[Keywords: Cancer; cancer stem cell; chromatin modification; DNA methylation; epigenetics]

${ }^{3}$ Corresponding author.

E-MAIL sbaylin@jhmi.edu; FAX (410) 614-9884.

Article is online at http://www.genesdev.org/cgi/doi/10.1101/gad.1464906.
Lachner and Jenuwein 2002). Transcriptional repression characterizes the bulk of the heavily DNA methylated mammalian genome and may safeguard against unwanted transcription of normally repressed DNA sequences (Bestor 1998). This DNA compaction also has an important role for the structural maintenance of proper chromosome replication (Okano et al. 1999; Xu et al. 1999; Tuck-Muller et al. 2000; Robertson 2005). In contrast, individual gene promoters or clusters of coordinately regulated genes are maintained in more open transcriptional configurations, which are dependent on states of chromatin balance involving differing ratios of active and repressive histone modifications (Bird and Wolffe 1999; Bernstein et al. 2002, 2005, 2006; Bird 2002; Boyer et al. 2006; Lee et al. 2006). Exciting information, on a genome-wide scale, has recently emerged to describe chromatin marks that accompany and/or allow cell lineage commitment steps (Bernstein et al. 2002, 2005, 2006; Boyer et al. 2006; Lee et al. 2006). This review explores how this information may be critical for understanding the epigenetic abnormalities in cancer and their role in the biology of tumor evolution.

One key component of the cancer epigenome is an altered DNA methylation pattern composed of global demethylation and promoter localized hypermethylation (Fig. 1). These changes fundamentally participate in an altered structure and function of DNA, potentially involving unwanted transcription of repeat elements, abnormal activation of individual genes (Bestor 1998; Bird 2002), predisposition to genomic instability through disruption of chromosome replication control (Narayan et al. 1998; Okano et al. 1999; Xu et al. 1999; Tuck-Muller et al. 2000), and finally, aberrant silencing of genes important to the initiation and progression of tumors (Jones and Laird 1999; Jones and Baylin 2002; Herman and Baylin 2003). The last abnormality is especially being recognized and involves many classic tumor suppressor genes, developmental transcription factors, tissue remodeling genes, DNA repair genes, cell cycle control genes, antiapoptotic genes, and genes that prevent abnormal activity of developmental pathways in tumors. In fact, any single cancer may simultaneously have all such genes epigenetically silenced (Baylin and Ohm 2006), and the loss of function of genes in tumors may have far more 


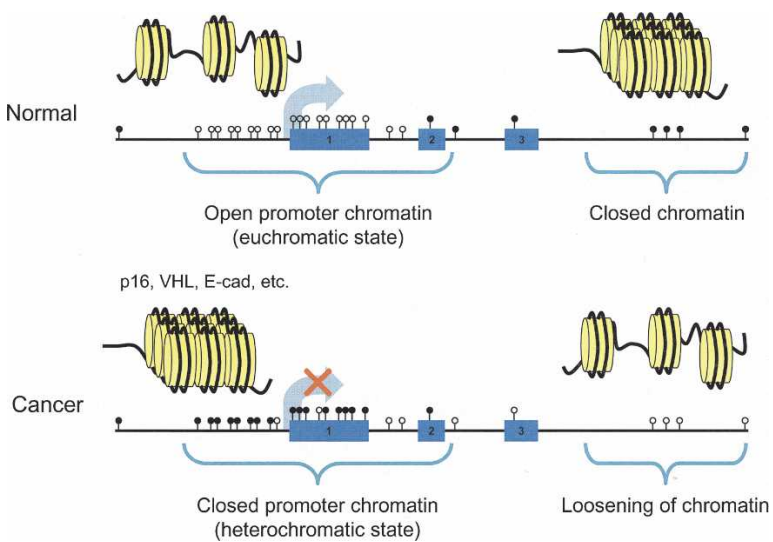

Figure 1. The normal versus cancer epigenome. (Top) In normal mammalian cells, CpG islands in proximal gene promoter regions (a three-exon gene is shown, with each exon marked in blue and numbered) are largely protected from DNA methylation (cytosines are shown as open lollipops) and reside in restricted regions of open chromatin (inset, upstream of transcription start shows three nucleosomes with wide spacing), or euchromatic states, favorable for gene transcription (large blue arrow). In contrast, for most regions of the genome, such as in the bodies of many genes and areas outside genes, particularly including repeat elements and pericentromeric regions, the cytosines in CpG dinucleotides are methylated (black lollipops). This DNA methylation is characteristic of the bulk of the human genome, which is packaged as closed chromatin (the inset above methylated CpGs shows multiple nucleosomes with higher-order, tight compaction) unfavorable for transcription. (Bottom) In cancer cells, there tends to be a reversal of this pattern. Proximal promoter CpG islands for many abnormally silenced genes (as represented by the same gene as shown in the top panel, and which is depicted as representing the tumor suppressor genes listed) become DNA hypermethylated and reside in a closed chromatin, or more heterochromatic-type state, which is not favorable for transcription (red X). In contrast, cytosines in $\mathrm{CpG}$ dinuleotides in other regions of the genome display hypomethylation and are associated with states of aberrantly loosened chromatin. The overall result is abnormal chromatin packaging with the potential for underpinning an abnormal cellular memory for gene expression and for conveying abnormal structural function for chromosomes.

epigenetic causes than genetic ones (Jones and Baylin 2002). In this review, we will particularly stress the emerging theme that epigenetic mechanisms may contribute to the earliest phases of tumor development and that links may exist between stem cell chromatin control and the vulnerability of genes to be epigenetically altered during tumorigenesis.

\section{The position of epigenetic abnormalities in tumor progression}

A full understanding of the impact of epigenetic changes in cancer depends on pinpointing at what stages of neoplastic evolution they occur and how they influence the biology of each progression step toward invasive disease. While epigenetic changes, like genetic alterations, may arise at any such steps, it is increasingly apparent that many chromatin-mediated abnormalities appear well before invasive cancer (Baylin and Ohm 2006; Feinberg et al. 2006). This fact potentially alters the view that all tumors begin with genetic mutations and, instead, places epigenetic changes as possible seminal events for tumor initiation (Baylin and Ohm 2006; Feinberg et al. 2006). These points link epigenetic changes in cancer to events that maintain stem/precursor cell phenotypes and how these contribute to tumorigenesis. They also connect epigenetics to cancer predisposition factors, such as aging, and cell responses to stress, such as occur in chronic inflammation, in terms of channeling cells into abnormal clonal expansion.

\section{Cancer, loss of gene imprinting, and the earliest steps in neoplasia}

The possibility for epigenetic origins of neoplasia is raised by abnormalities in gene imprinting found in cancer. Normal imprinting, mediated by both DNA methylation and histone modifications, ensures paternally determined, heritable transcriptional expression of one gene allele and repression of the other (Surani 1991, 1993; Bartolomei and Tilghman 1997; Ferguson-Smith and Surani 2001). Several genes undergo loss of imprinting (LOI) in cancers, such that both alleles are expressed in the tumor (Feinberg and Tycko 2004; Feinberg 2005; Holm et al. 2005; Feinberg et al. 2006). The potential for tumorigenesis to ensue in such a setting is evident from development wherein embryos derived strictly from maternal source form ovarian teratomas and those strictly from paternal source form hydatidiform moles/choriocarcinomas. Perhaps the most well studied example in adult cancers is the IGF2 gene, whose biallelic expression would result in overproduction of a potent growth factor (Feinberg and Tycko 2004; Feinberg 2005; Holm et al. 2005; Feinberg et al. 2006). LOI for IGF2 is found in normal-appearing colonic epithelium of patients with colorectal cancer and may be associated with increased risk of colon cancer even when found in circulating white cells (Cui et al. 2003; Kaneda and Feinberg 2005; Sakatani et al. 2005). The LOI mechanism is a complicated one. Abnormal increase of promoter DNA methylation in the $\mathrm{H} 19$ gene accompanies its transcriptional silencing and transfer of enhancer control for this gene more distally on the same chromosome, resulting in biallelic IGF2 expression (Bartolomei 2003; Kato and Sasaki 2005). Recent work in an animal model solidifies that such LOI might initiate tumorigenesis. The intestinal epithelium of mice engineered for Igf2 biallelic expression has a higher proportion of progenitor to differentiated cells as may also occur in humans with constitutive biallelic expression of IGF2 (Sakatani et al. 2005). Another example wherein LOI of IGF2 appears to produce abnormal progenitor cell expansion without an associated genetic alteration is in the formation of a subset of Wilm's tumors, a childhood renal cancer. In this setting, the biallelic expression appears to foster abnormal expansion of a renal progenitor cell pool yielding the 
substrate for later cancer progression events (Feinberg et al. 2006).

Finally, a recent elegant mouse model further ups the ante for abnormal imprinting as an initiation event for cancer. The authors developed a mouse model with substantial loss of gene imprinting through transient germline DNA demethylation produced via regulated disruption of the maintenance DNA methyltransferase, Dnmt1 (Holm et al. 2005). Embryonic fibroblasts from these mice formed tumors in immunocompromised mice and have properties of spontaneously immortalized cells in vitro. Furthermore, these cells can be fully transformed in one step with the introduction of the $H$-Ras oncogene. Finally, chimeric animals derived from embryonic stem (ES) cells from the engineered mice developed multiple tumors. The authors concluded from the findings that "LOI alone can predispose cells to tumorgenesis and identify a pathway through which immortality conferred by LOI lowers the threshold for transformation" (Holm et al. 2005). Clearly, this study and all the work discussed above for LOI vividly illustrate the concept that a switch in heritable gene expression patterns, in the absence of mutations, may lead to abnormal expansion of stem/progenitor cells and, thus establish a risk that subsequent events will promote full transformation and evolution of cancer.

\section{Cancer, aberrant transcriptional repression, and the earliest steps in neoplasia}

As mentioned earlier, perhaps the most intensely studied epigenetic abnormality in cancer is the aberrant transcriptional silencing of genes associated with DNA hypermethylation of promoter region $\mathrm{CpG}$ islands. There are many hints that this epigenetic abnormality, like LOI, could be seminal in neoplastic evolution. For example, one of the most common tumor suppressor genes affected in many tumor types by this loss of function event is $p 16^{i n k 4 A}$. The DNA hypermethylation of this gene is observed during progression of tumors such as lung cancer as early as preneoplastic lesions (Belinsky et al. 1998; Nuovo et al. 1999; Belinsky 2004) and recent data in knockout mice indicate that germline loss of this gene can increase stem cell life span (Janzen et al. 2006; Krishnamurthy et al. 2006; Molofsky et al. 2006). Experimentally, loss of $p 16^{\text {ink } 4 A}$ appears to facilitate early tumorigenesis by being permissive for subsequent emergence of genomic instability (Foster et al. 1998; Kiyono et al. 1998) and may directly allow for additional epigenetic silencing of other genes (Reynolds et al. 2006). Other evidence for the early tumorigenic role of epigenetic gene silencing comes from additional studies of classic tumor suppressor genes. Germline mutations of these genes cause familial forms of cancer through mechanisms that obviously result in early expansion abnormalities (Hanahan and Weinberg 2000). To a variable extent, these same genes are found to be DNA hypermethylated in subsets of nonfamilial cancers such as $V H L$ in renal, $A P C$ in colon, and BRCA1 in breast cancers (Herman et al. 1994; Esteller et al. 2000a, b; Heden- falk et al. 2001; van 't Veer et al. 2002). While it is possible that these epigenetic changes could be late events in the nonfamilial tumor setting, it is just as likely they could affect adult precursor cells in early neoplastic stages. Interestingly, for example, identical patterns of microarray gene expression occur in breast cancers from patients who have germline $B R C A 1$ mutations and familial breast cancers as in sporadic nonfamilial breast cancers, which harbor hypermethylated BRCA1 genes (Hedenfalk et al. 2001; van 't Veer et al. 2002).

Most recently, studies of hypermethylated genes identified by emerging techniques to screen cancer cell genomes for epigenetic changes (Ushijima 2005) are revealing a potential network of epigenetic events that, again, stress the theme that epigenetic alterations may have pivotal involvement in abnormal clonal expansion of stem/progenitor cells and predisposition to cancer. One such situation involves the Wnt developmental pathway, which is essential for stem/progenitor cell function, expansion, and maintenance in the normal intestine and elsewhere during embryogenesis and adult cell renewal (Gregorieff and Clevers 2005; Radtke and Clevers 2005). This pathway is canonically overactive in colon cancer via mutations in downstream pathway genes such as APC and $\beta$-catenin (Kinzler and Vogelstein 1996; Morin et al. 1997; Fodde et al. 2001; Gregorieff and Clevers 2005; Radtke and Clevers 2005). A family of secreted frizzled related genes (SFRPs), which encode for proteins that antagonize Wnt activation at the cell membrane (Finch et al. 1997; Rattner et al. 1997; Lacher et al. 2003), are epigenetically silenced early during colon cancer progression and in virtually every established colon cancer (Suzuki et al. 2002, H. Suzuki et al. 2004; Akino et al. 2005). The early silencing of these genes may constitute broaching of an "epigenetic gate keeper" step prior to the downstream mutations in APC or $\beta$-catenin, or the loss of "genetic gatekeeper steps," to activate the Wnt pathway, start colon tumorigenesis, and later to collaborate with the mutations to provide for a fully activated Wnt pathway to promote tumor progression (Baylin and Ohm 2006).

Another fascinating possibility for fostering early abnormal clonal expansion involves a network of epigenetic events linking sustained increases in SIRT1 to the tumor suppressor, p53, and to generalized silencing of cancer genes. SIRT1 is a multitasking, stress-sensing protein and is a member of the class III histone deacetylases (HDACs) or sirtuins. SIRT1 deacetylase activity can post-translationally modify p53 to down-modulate its transcriptional activity (Luo et al. 2001; Vaziri et al. 2001; Langley et al. 2002). Normal tissue responses to cell stress and injury are transient and must coordinate cell renewal, tissue repair, and apoptotic responses. The latter, dependent upon cell cycle checkpoints mediated by p53 (Sharpless and DePinho 2002), prevent cell survival following cytokine exposure and increases in reactive oxygen species (ROS) that can generate DNA damage (Nelson et al. 2004; Bartsch and Nair 2005; Nagata 2005; Lu et al. 2006). These normal responses to acute inflammation and wound healing then use feedback cir- 
cuits to modulate resistance to stress such that cell repopulation occurs and then properly ceases /Coussens and Werb 2002; Balkwill and Coussens 2004; Nelson et al. 2004; Lu et al. 2006). Abnormally proplonged survival responses during chronic exposure to such stress may often be at the heart of abnormal clonal expansion, which promotes tumor risk.

The first focal point of an epigenetic circuit that links SIRT1 to such abnormal survival responses (Fig. 2) involves silencing of HIC1, which occurs early in progression of major tumors (Wales et al. 1995; Eguchi et al. 1997; Fujii et al. 1998; Hayashi et al. 2001). HIC1, a member of the zinc finger containing POZ family transcriptional repressors (Bardwell and Treisman 1994; Zollman et al. 1994), was discovered in a random search for hypermethylated genes in a frequent deletion area of chromosome region $17 \mathrm{p} 13.3$, and is itself a transcriptional activation target of p53 (Wales et al. 1995; Guerardel et al. 2001). HIC1 and SIRT1 form a complex that localizes to the SIRT1 promoter and suppresses its transcription (Chen et al. 2005). Hic1 homozygous knockout mice have multiple lethal epithelial defects (Carter et al. 2000), eightfold increased levels of Sirt1 in embryonic fibroblasts (Chen et al. 2005), and the heterozygotes are tumor prone (Chen et al. 2003). When crossed with p53 heterozygotes, a new spectrum of virulent tumors is induced (Chen et al. 2004). Thus, the epigenetic loss of HIC1 function (Fig. 2) can then potentially blunt normal

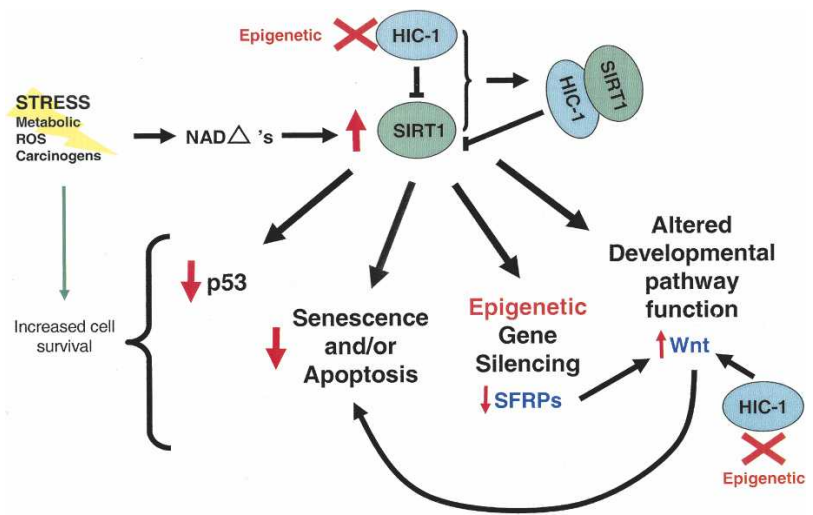

Figure 2. Epigenetic silencing of $\mathrm{HICl}$ - a potential model for how a network of epigenetic abnormalities may facilitate abnormal cellular expansion. Under normal cellular conditions, cellular stress response signals to genotoxic stresses, such as a build-up of ROS, lead to changes in the balance between NAD and NADH and induction of SIRT1 expression. This response in normal cells aids cell survival to allow repair in a transient manner. This response is then suppressed through feedback steps involving HIC1-SIRT1 complex formation, transcriptional repression of SIRT1 expression, and p53 activation of $\mathrm{HICl}$ as described in the text. However, during chronic cell renewal, epigenetic inactivation of HIC1 (red Xs), a frequent early event in tumorigenesis, can lead to abnormal cell survival and clonal expansion. This involves chronic SIRT1 increases, and participation of this protein in suppression of p53 function, epigenetic silencing of additional genes, and increases in WNT pathway activity through loss of expression of SFRPS and direct loss of HIC1 modulation of WNT pathway transcription. cellular responses to p53 through SIRT1 increases and, potentially, increase cell life span through this route. Even one copy increases of the SIRT1 homolog Sir2 can prolong the life span of cells in organisms from Caenorhabditis elegans to mammals (Kaeberlein et al. 1999; Lin et al. 2000; Tissenbaum and Guarente 2001; Howitz et al. 2003). Hic1-deficient mouse and human cancer cells have a p53- and SIRT1-dependent reduction in apoptotic responses to DNA damage (Chen et al. 2005). Taken together (Fig. 2), early heritable loss of HIC1 expression could trigger blunting of apoptosis and prolongation of cellular life span to facilitate early abnormal clonal expansion in settings, such as chronic inflammation, that predispose to cancer.

The next step in the potential network of SIRT1 events would suggest epigenetic events that beget epigenetic events. Among the targets for SIRT1 deacetylase activity are histone amino acids such as Lys 16 of histone $\mathrm{H} 4$ (H4K16) and H3K9. These modifications are key for a role of the yeast SIRT1 ortholog Sir2 in maintaining transcriptional silencing for genes in telomeric and mating loci regions (Guarente 2000; Kimura et al. 2002; Suka et al. 2002). Additionally, in Drosophila, Sir2 participates in long-term maintenance of gene silencing fundamental for development and stem cell function (Furuyama et al. 2004). SIRT1 appears to play a similar role in the transcriptional silencing of DNA hypermethylated cancer genes by localizing to the promoters of such genes to deacetylate $\mathrm{H} 4 \mathrm{~K} 16$ and H3K9. Induced decreases in SIRT1 activity, thus, results in re-expression of the silenced genes (Pruitt et al. 2006). For example, this experimental depletion of SIRT1 in cancer cells results in reactivation of the silenced Wnt antagonist genes, the SFRPs, and thus reverses the overactivity of Wnt pathway in breast and colon cancer cells (Fig. 2; Pruitt et al. 2006). A final nodal point for epigenetic silencing of HIC1 involves other routes by which silencing of this gene results in overactivity of the Wnt pathway. HIC1 can associate with TCF-4 and thus recruit $\beta$-catenin to localized nuclear structures, termed HIC1 bodies (Fig. 2). This HIC1 activity then normally helps prevent formation of nuclear $\beta$-catenin-TCF complexes that would otherwise drive canonical Wnt pathway activity (Valenta et al. 2006).

In summarizing this first section, there is compelling evidence, from deregulation of gene imprinting to aberrant transcriptional silencing of genes, that epigenetic abnormalities may play an influential role in allowing abnormal clonal expansion and initiating the neoplastic cascade. How these heritable abnormalities in gene expression patterns come to exist in neoplastic cells and how the mechanisms involved relate to normal epigenetic control of gene expression are explored in the remainder of this review.

\section{Components of control for DNA methylation and chromatin, packaging of the genome, and cancer}

If epigenetic abnormalities of gene expression are especially important to stem/precursor cell contribution to 
the earliest stages of neoplasia, how do we begin to understand the molecular underpinnings for their appearance? The answers lie in dissecting the growing appreciation of how chromatin construction and DNA methylation recruitment are joined, and how these events differ between normal stem/precursor cells and neoplastic cells.

\section{The DNA methylation machinery}

As discussed, epigenetic abnormalities in cancer include both losses and gains of DNA methylation (Feinberg and Vogelstein 1983; Feinberg et al. 1988; Jones and Laird 1999; Jones and Baylin 2002; Feinberg and Tycko 2004; Baylin and Ohm 2006) and we understand more about the latter. DNA methyltransferases (DNMTs), which catalyze the covalent addition of methyl groups to cytosines in the CpG dinucleotide context, have been incriminated in the DNA methylation abnormalities in cancer. Overexpression of DNMT1 induces transformation of NIH 3T3 cells (Wu et al. 1993) and contributes to cell transformation by the Fos oncogene (Bakin and Curran 1999). Inhibition of DNMT activities by 5 -aza-2'deoxycytidine, a cytosine analog, delays large $\mathrm{T}$ antigen (TAg)-induced prostate cancer transformation in the TRAMP mouse model (Czermin et al. 2002) and lung cancer development in a rodent carcinogenesis model (Belinsky et al. 2003). Elevated levels of DNMT proteins and activities occur in various cancer types, including gastric, bladder, leukemia, colon, and lung (Issa et al. 1993; Belinsky et al. 1996; Melki et al. 1998; De Marzo et al. 1999; Robertson et al. 1999; Ramsahoye et al. 2000; Wagner et al. 2003; Etoh et al. 2004; Agoston et al. 2005).

Most of what we know about how mammalian DNA methylation patterns are established comes from studies of mouse normal development. Homozygous deletion of any of the three Dnmt loci encoding catalytically active Dnmts, Dnmt1, Dnmt3a, and Dnmt3b, is lethal (Li et al. 1992; Lei et al. 1996; Okano et al. 1999). In this regard, deletion of Dnmt3a and Dnmt3b abolishes de novo methylation, while Dnmt1 deletion produces bulk DNA demethylation, reflecting a maintenance methyltransferase role for this enzyme (Okano et al. 1999) consistent with in vitro enzymatic studies (Gruenbaum et al. 1982; Pedrali-Noy and Weissbach 1986). The above paradigm for embryonic separation of maintenance versus de novo Dnmt activities has been challenged in the cancer setting. Using both genetic deletion and RNA interference (RNAi) approaches in human colon and other cancer cells (Rhee et al. 2000, 2002; Ting et al. 2004, 2006), severe depletion of DNMT1 has produced only minor decreases in overall DNA methylation, minimal loss of promoter hypermethylation, and undetectable re-expression of silenced tumor suppressor genes. Undeniably, there have been controversies regarding such lack of requirement for DNMT1 in maintaining promoter hypermethylation and gene silencing in cancer cells, and some investigators have found changes in the above parameters in cancer cells with DNMT1 depletion (Robert et al. 2003; Yan et al. 2003; M. Suzuki et al. 2004). Most recently, small amounts of a cryptic splice form of DNMT1 has been found in HCT116 DNMT1 ${ }^{-/-}$colon cancer cells, which may be sustaining them (Egger et al. 2006). One resolution to some of the above differences may be that threshold requirements differ for DNMT1 in various cancers. In our own studies of RNAi-induced depletion of DNMT1, we identified one cell line, T47D breast cancer cells, that displayed an essential requirement for retention of substantial DNMT1 levels for maintaining DNA methylation and cell survival (Ting et al. 2006). Yan et al. (2003) also found a specific requirement for DNMT1 in MDA-MB-231 and Hs578t breast cancer cell lines for maintaining Estrogen Receptor methylation and repression.

The biology behind this differential requirement for DNMT1 may involve cooperativity between DNMTs for maintenance of DNA methylation in human cancer cells. In HCT116 colon cancer cells, knockout of DNMT3b, the conventional de novo methyltransferase, from DNMT1 ${ }^{-1-}$ HCT116 cells (double knockout or DKO cells) results in a $>95 \%$ loss in genomic 5-methyl cytosines and complete promoter demethylation and reexpression of aberrantly silenced genes (Rhee et al. 2002; Akiyama et al. 2003; Paz et al. 2003; Satoh et al. 2003; H. Suzuki et al. 2004). Multiple DNMTs are being colocalized to promoters of hypermethylated genes and defined as components of transcriptional repression complexes (Di Croce et al. 2002; Kim et al. 2002; Datta et al. 2003). However, the precise interactions between these proteins require further investigation.

The above discussion relates primarily to the maintenance of DNA methylation in cancer, but what establishes the patterns to start with? For example, does DNMT1 contribute to de novo methylation and to aberrant promoter $\mathrm{CpG}$ island methylation and abnormal gene silencing? DNMT1 has low intrinsic de novo activity against unmethylated substrates, and there is a lack of in vivo evidence for Dnmtl de novo methylation in the murine ES cell system (Lei et al. 1996) and in studies of its ectopic expression of DNMT1 in Drosophila (Lyko et al. 1999). However, overexpression of the protein results in detectable de novo methylation of CpG island sequences in human fibroblasts (Vertino et al. 1996). Unmethylated human $\mathrm{CpG}$ islands are robust substrates for DNMT1 de novo DNA methylation activity, and overexpression of DNMT1 in cultured Drosophila cells can specifically establish methylation on these substrates when they are stably incorporated into the fly genome (Jair et al. 2006). DNMT1 in HCT116 colon cancer cells may account for $50 \%$ of the de novo methyltransferase activity against these substrates in vitro (Jair et al. 2006). DNMT1 may, then, be capable of initiating aberrant $\mathrm{CpG}$ island hypermethylation at least in cancer cells.

\section{Chromatin conformation, remodeling, histone modifications, and the cancer epigenome}

To understand the origins of epigenetic alterations in cancer, we must tap the explosion of knowledge about molecular control for organizing and maintaining the 
chromatin structure of the normal nucleus and how histone modifications, including lysine acetylation, lysine and arginine methylation, serine and threonine phosphorylation, glutamic acid ADP-ribosylation, and lysine ubiquitination and sumoylation participate in this process. Positioning of the nucleosome with its 147 base pairs of DNA wrapped around the octamer of the core histones, $\mathrm{H} 2 \mathrm{~A}, \mathrm{H} 2 \mathrm{~B}, \mathrm{H} 3$, and $\mathrm{H} 4$, in conjunction with the above modifications of histones, modulates the normal epigenome in terms of maintaining gene expression patterns and normal chromosome structure and function (Jenuwein and Allis 2001). These components are delicately balanced, and small changes in a given parameter can have major consequences for cell phenotype and transcriptional patterns. In yeast, a single copy change in the histone deactylase Sir2 can completely alter zones of gene silencing with respect to telomeric versus more proximal chromosome distribution (Kimura et al. 2002; Suka et al. 2002). It is not hard to imagine, then, that in cancer cells, global and local shifts of DNA methylation and chromatin parameters would have great impact. Cancers have not only altered DNA methylation but also global changes in the levels of proteins that participate in chromatin modifications, such as polycomb complex constituents, and in histone modifications, such as acetylation and methylation of lysine residues on histones H3 and H4 (Varambally et al. 2002; Kirmizis et al. 2003; Kleer et al. 2003; Fraga et al. 2005; Seligson et al. 2005).

\section{DNA methylation and chromatin connections}

There is tight interdependence between DNA methylation and chromatin modifications for DNA packaging. Select type I and II HDACs, which mediate removal of acetyl groups from histone lysine residues, are associated both with complexes involving each of the DNMTs and with a family of methyl cytosine-binding proteins, MBDs, which interpret and mediate the transcriptional repressive activities of DNA methylation (Bird and Wolffe 1999; Robertson et al. 2000; Rountree et al. 2000; Bachman et al. 2001; Fuks et al. 2001; Bird 2002; Burgers et al. 2002). The MBDs have potential for gene promoter specificity and have been localized to DNA hypermethylated and aberrantly silenced cancer genes (Nguyen et al. 2001; Bakker et al. 2002; El-Osta et al. 2002; Koizume et al. 2002; Darwanto et al. 2003; Muller et al. 2003; Ballestar and Esteller 2005). Typically, actively transcribed genes are surrounded by acetylated histones but by deacetylated histones when aberrantly silenced in cancer in association with DNA hypermethylation (Cameron et al. 1999; Fahrner et al. 2002; Nguyen et al. 2002; Kondo et al. 2003; McGarvey et al. 2006). In this apparent collaboration between DNA methylation and lysine deacetylation, the methylation appears dominant in that it must be diminished by the demethylating agent, 5-aza-2'-deoxycytidine, before cellular inhibition of the type I and II HDACs can effectively achieve transcriptional reactivation of the genes (Cameron et al. 1999; Suzuki et al. 2002). This demethylation also causes release of the MBDs, and presumably of the HDACs, from the promoters (Nguyen et al. 2001; Bakker et al. 2002; El-Osta et al. 2002; Koizume et al. 2002; Darwanto et al. 2003; Muller et al. 2003).

Contrary to the above scenario, SIRT1, a class III HDAC, participates in the aberrant silencing of cancer genes but acts differently with respect to promoter DNA hypermethylation. For SIRT1-target genes, concomitant increases in acetylation of H4K16, and to a lesser extent H3K9, induced by inhibition of SIRT1 occur without any loss of the promoter DNA methylation and may, then, modulate the transcriptional repression downstream from DNA methylation (Pruitt et al. 2006). The exact mechanisms involved, and the holistic role of SIRT1 in both establishing and maintaining sites of DNA methylation, becomes important with the recent association of SIRT1 with protein complexes fundamental to longterm gene silencing in stem/precursor cells (Kuzmichev et al. 2005).

While acetylation of histone lysines is associated with active transcription, methylation of these residues associates with either active or repression states depending upon the modified site (Strahl and Allis 2000; Jenuwein and Allis 2001; Briggs et al. 2002). The acetylation dynamics are balanced by actions of histone acetyltransferases (HATs) and HDACs, and histone methylation was recently recognized as also being dynamically regulated by histone methyltransferases (HMTs) and histone demethylases (Shi et al. 2004, 2005; Forneris et al. 2005; Metzger et al. 2005; Fodor et al. 2006; Tsukada et al. 2006; Yamane et al. 2006). The complex nature of the "histone code" is further expanded by the presence of mono, di, and tri forms of lysine methylation, each form being catalyzed by a different HMT (Rea et al. 2000; Lachner and Jenuwein 2002; Rice et al. 2003; Lachner et al. 2004). For example, trimethylation of histone H3 Lys 9 (H3K9me3) is associated with the compaction and transcriptionally repressive characteristics of pericentromeric heterochromatin, while $\mathrm{H} 3 \mathrm{~K} 9 \mathrm{me} 2$ is more associated with euchromatic gene silencing (Lachner et al. 2003; Gibbons 2005). Histone acetylation and methylation patterns are translated by effector proteins, as is DNA methylation through the MBDs. Proteins containing bromodomains, which recognize acetylated lysine residues, and chromodomains, which bind to methylated lysine residues, are targeted to the histones and cause changes in gene transcription and genome organization (Jacobs et al. 2001; Plath et al. 2003).

Cancer-associated DNA hypermethylated and silenced genes can be models to examine chromatin control of gene expression. When such genes are not DNA methylated, and basally expressed, their promoters have a virtually identical distribution of the active marks, H3K9acetyl and H3K4me (Fahrner et al. 2002; Ghoshal et al. 2002; Nguyen et al. 2002; Kondo et al. 2003; Kondo and Issa 2004; McGarvey et al. 2006). In contrast, when silenced in cancer cells and associated with DNA methylation, these active marks are severely diminished, and virtually every histone methylation mark, including mono-, di-, and trimethylation of $\mathrm{H} 3 \mathrm{~K} 9$ and $\mathrm{H} 3 \mathrm{~K} 27$, that 
has best been associated with transcriptional repression is enriched (McGarvey et al. 2006). As previously noted, $\mathrm{H} 3 \mathrm{~K} 9 \mathrm{me} 3$ is associated with the tightly closed configuration of pericentromeric heterochromatin, $\mathrm{H} 3 \mathrm{~K} 9 \mathrm{me} 2$ is more associated with euchromatic gene silencing, and $\mathrm{H} 3 \mathrm{~K} 27 \mathrm{me}$ is associated with facultative heterochromatin, such as that for silenced genes on the inactive $\mathrm{X}$ chromosome of mammalian female cells (Lachner et al. 2003). H3K27me is placed by the polycomb protein complexes (PcG) that, from Drosophila to man, mediate long-term gene silencing (Orlando 2003; Lund and van Lohuizen 2004a,b; Ringrose and Paro 2004; Schwartz et al. 2004; Pirrotta and Gross 2005) and, as noted below, has a potentially critical role in the origins of cancer gene silencing.

\section{HMTs and PcG}

The promoters of DNA hypermethylated cancer genes are enriched for enzymes known to catalyze the above silencing histone methylation marks including G9a and EuHMTase for H3K9me2 and EZH2 for H3K27me (McGarvey et al. 2006). The origins of the H3K9me3 mark is not known, although at pericentromeric heterochromatin, this modification is established by SuVar HMT family members (Melcher et al. 2000; Peters et al. 2001; Maison et al. 2002; Lehnertz et al. 2003; Ebert et al. 2004; Krouwels et al. 2005). H3Kme2 and H3K9me3 are recognized by chromodomain proteins, including HP1 family proteins (Aagaard et al. 1999; Melcher et al. 2000; Rea et al. 2000; Schotta et al. 2002, 2003; Rice et al. 2003; Krouwels et al. 2005; Chin et al. 2006), and HP1 $\alpha$ localizes to the promoters of DNA hypermethylated and silenced cancer genes (McGarvey et al. 2006). Interestingly, the tumor suppressor $\mathrm{Rb}$ may participate in targeting $\mathrm{H} 3$ methylation and binding of $\mathrm{HP} 1 \alpha$ to target genes, suggesting a role for SUV39H1 in euchromatic gene repression and heterochromatic silencing (Aagaard et al. 2000; Nielsen et al. 2001).

One approach to further understand the roles of these components and events in the maintenance, and even the origins, of aberrant gene silencing in cancer is to exploit the reversible nature of epigenetics and monitor the chromatin responses. Several groups have induced re-expression of DNA hypermethylated and silenced cancer genes through 5-aza-2'-deoxycytidine-induced DNA demethylation, or examined demethylated genes in the HCT116 DKO colon cancer and noted reappearance of the active marks H3K9acetyl and H3K4me (Fahrner et al. 2002; Ghoshal et al. 2002; Nguyen et al. 2002; Kondo et al. 2003; McGarvey et al. 2006). However, while these active marks are enriched, only one silencing mark, $\mathrm{H} 3 \mathrm{~K} 9 \mathrm{me} 2$, is strikingly decreased, while each of the other repressive marks, H3K9me3, H3K27me2, and H3K27me3, are retained (McGarvey et al. 2006). This may incriminate $\mathrm{H} 3 \mathrm{~K} 9 \mathrm{me} 2$ in the maintenance and/or the origins of the silencing and suggest that the polycomb complex-induced H3K27me mark may have more to do with origins of the gene silencing than with its maintenance.
Conclusive proof for the precise roles of each of the defined transcriptional repressive marks in the maintenance and the origins of aberrant gene silencing in cancer remains to be garnered. In terms of a hierarchy of events, debate continues as to whether DNA methylation initiates the silencing or is superimposed upon it. Data supporting a role for DNA methylation affecting histone methylation exist for Arabidopsis, wherein removal of the maintenance DNA methyltransferase results in loss of H3K9 methylation in heterochromatin (Tariq et al. 2003). Further evidence in human cells shows that loss of DNMT1 results in a decrease of $\mathrm{H} 3 \mathrm{~K} 9 \mathrm{me} 2$ and H3K9me3 (Espada et al. 2004). However, it seems that evidence is building to suggest a primary role for histone modifications in starting aberrant gene silencing. First, in Neurospora crassa, the HMT dim-5, which catalyzes $\mathrm{H} 3 \mathrm{~K} 9 \mathrm{me} 3$, is required for DNA methylation while in Arabodopsis, the HMT KRYPTONITE is necessary for CpNpG methylation by CHROMOMETHYLASE3 (Tamaru and Selker 2001; Jackson et al. 2002, 2004; Johnson et al. 2002; Tamaru et al. 2003). Second, mouse ES cells null for the HMT Suv39h display altered DNA methylation at pericentromeric satellite repeats while Dnmt1 single- or Dnmt3a/3b double-deficient mouse ES cells do not impair H3K9 methylation (Lehnertz et al. 2003). Also, studies on mouse ES cells lacking G9a, one of the enzymes responsible for the H3K9me2 mark, suggest a role for histone methylation in the maintenance of imprinted regulatory regions (Xin et al. 2003). In human cancer cells, histone deacetylation and H3K9 methylation precede resilencing and re-DNA-methylation of the $p 16^{\text {ink } 4 a}$ gene, which recur after initial DNA demethylation and re-expression in the DKO cells (Bachman et al. 2003).

Finally, ever increasing evidence suggests a particularly critical role for PcG proteins in epigenetic cancer gene dysfunction (Lund and van Lohuizen 2004b; Muyrers-Chen et al. 2004; Valk-Lingbeek et al. 2004). The PcG complexes play an essential role in development through establishment of long-term gene silencing in Drosophila (Orlando 2003; Lund and van Lohuizen 2004a; Ringrose and Paro 2004; Schwartz et al. 2004; Pirrotta and Gross 2005). These complexes exist in at least four groups, including the maintenance complex, PRC1, consisting of RNF2, HPC, ECR, and BMI1, and different initiation complexes, PRC2 through PRC4, which contain EZH2, SUZ12, and different isoforms of EED /Orlando 2003; Kirmizis et al. 2004; Kuzmichev et al. 2004, 2005; Lund and van Lohuizen 2004a; Ringrose and Paro 2004; Schwartz et al. 2004; Pirrotta and Gross 2005). The SET domain of EZH2 is responsible for the contribution of the PRC2 complex to methylation of both H3K27 and H1K26. As noted, H3K27me is found at the promoters of all the DNA hypermethylated and silenced cancer genes examined (McGarvey et al. 2006). Interestingly, the exact composition of the complex may direct which histone residue is methylated by EZH2 (Kuzmichev et al. 2004, 2005). Increased levels of EZH2 have been implicated in several types of cancer, and the expression level correlates with prognosis in both prostate and breast can- 
cer (Varambally et al. 2002; Bracken et al. 2003; Kleer et al. 2003; Bachmann et al. 2006; Matsukawa et al. 2006). SUZ12, another key PRC2 constituent, is also up-regulated in several tumor types, including colon, breast, and liver (Bracken et al. 2003; Kirmizis et al. 2004; Reynolds et al. 2006). The PRC1 component Bmil has also been reported as elevated in cancer and can initiate aspects of abnormal clonal expansion fundamental to development of hematopoietic and brain tumors (Lessard et al. 1999. Leung et al. 2004; Lund and van Lohuizen 2004b; Bruggeman et al. 2005). Most recently, EZH2 has been linked with gene targeting for all three mammalian DNMTs and suggested to have roles in both the triggering of DNA methylation and its maintenance in gene silencing (Vire et al. 2006). Bmil is also reported to colocalize with DNMT1 (Hernandez-Munoz et al. 2005). These initial findings need to be verified and extrapolated to other normal and neoplastic DNA methylation events.

Importantly, the role of PcG complexes in gene silencing intersects with recent findings of a role for the deacetylase SIRT1 at silenced cancer gene promoters (Pruitt et al. 2006). In flies, overexpression of EZH2 promotes formation of a newly defined polycomb complex, PRC4, which appears to contain SIRT1 and a specific isoform of Eed termed Eed2 (Furuyama et al. 2004; Kuzmichev et al. 2004; Chopra and Mishra 2005). In this complex, SIRT1 deacetylates H1K26 and EZH2 preferentially methylates this residue. Interestingly, cancer cells display elevated levels of PcG proteins, including all four isoforms of EED as well as SIRT1 while these proteins are barely detectable in nontumor cells (Kuzmichev et al. 2005). A mouse model for human prostate cancer additionally demonstrated increased EZH2 and SIRT1 levels in cancer-derived tissues versus normal prostate (Kuzmichev et al. 2005). Thus, the role of SIRT1, in concert with PcG complexes, may be critical for maintenance of aberrant gene silencing in cancer, emphasizing again the remarkable potential network of cellular events outlined in Figure 2.

\section{Stem cells, cancer stem cells, yeast models, and the cancer epigenome}

How can we weave all of the data discussed in this review into a working model for understanding further the origins of the cancer epigenome and particularly the most intensely studied component, epigenetic gene silencing? Key clues may relate to the very large numbers of such silenced genes in cancer cells. Random screening of the cancer genome for aberrantly silenced genes is predicting that any given cancer may harbor hundreds of these latter genes (Suzuki et al. 2002). In most cases, the silencing appears to involve individual genes interspersed throughout a wide range of chromosome regions, but large areas of involvement for a chromosome arm have recently been reported for colon cancers (Frigola et al. 2006). In colon and other cancers, Issa and colleagues (Issa 2004) have identified what they have termed a CpG island methylator phenotype, or "CIMP." While this notion has been challenged by some (Yamashita et al.
2003), most recent data appear to validate the concept (Weisenberger et al. 2006). These large-scale gene-silencing events certainly could represent stochastic changes accruing during tumor progression. However, it seems more likely a program might exist to predispose groups of genes to the chromatin alterations associated with such a large amount of genomic transcriptional repression. We speculate that recent findings for chromatin control of gene expression for stem cell biology may be providing a major clue to how groups of cancer genes would undergo such coordinated transcriptional repression.

It is an old concept that many cancers may arise through a series of progression steps, with resultant increase in cellular heterogeneity, in a clone of abnormally expanding adult stem cells (Reya et al. 2001; Lund and van Lohuizen 2004b; Muyrers-Chen et al. 2004; ValkLingbeek et al. 2004; Bjerkvig et al. 2005). New views of such "cancer stem cells" emphasize they may be responsible for continued population of the cancer rather than their progeny cells. Certainly, recent experimental evidence suggests that molecular events that lock in a degree of "stemness" in neoplastic cells can drive tumor progression. Thus, in a mouse model, conditional germline overexpression of the stem cell gene Oct4 can drive rapid tumorigenesis in epithelial cells of the intestine and other organs (Hochedlinger et al. 2005).

What could be the targets for such a stem cell-driven neoplasia in terms of the cancer epigenome? We suggest that recent observations by several groups concerning how ES and progenitor cells use chromatin organization to maintain their status may hold the answer. In both murine and human ES cells, transcription factors specifying for cell stemness, including OCT4, NANOG, and $S O X 2$, are localized to promoter regions of a restricted group of some 1000 genes for each factor, and some 350 target genes for all three (Boyer et al. 2006; Lee et al. 2006). These target genes, including transcription factors, genes guiding cell proliferation control, morphogenesis regulating genes, etc., have one central theme in that all are generally related to the pluripotency of stem cells (Beach et al. 2005; Bernstein et al. 2006; Boyer et al. 2006; Lee et al. 2006). Importantly, the target genes are largely maintained at low expression states in ES cells by having a zone spanning their proximal promoter regions characterized by PcG proteins and the pivotal repressive mark, H3K27me3 (Bernstein et al. 2006; Boyer et al. 2006; Lee et al. 2006). Also, such genes usually have proximal promoter $\mathrm{CpG}$ islands and sequences outside gene coding regions that are conserved between mouse and man (Bernstein et al. 2006).

The PcG occupancy of the above promoters appears to function for preventing their full expression until ES and other precursor cells are signaled to undergo commitment steps toward cell lineages (Bernstein et al. 2006; Boyer et al. 2006; Lee et al. 2006). Importantly, this dictates that the maintained ES expression state must preserve gene expression plasticity such that PcG influences can be reversed or diminished when gene expression is required (Bernstein et al. 2006). In subsequent 
maturation steps, or in adult cell differentiation, the role of PcG complexes may come back into play in that their maintenance of long-term gene silencing is seen in mature stem/precursor cells as well (Orlando 2003; Lund and van Lohuizen 2004a; Ringrose and Paro 2004).

Another defining chromatin feature of the above PcG target genes in ES cells has been observed that may also have a special link to aberrant silencing of genes in cancer. Surprisingly, within the broad zone of PcG localization surrounding their promoters, as marked by the distribution of $\mathrm{H} 3 \mathrm{~K} 27 \mathrm{me} 3$, there is a narrower zone distinctly marked by the presence of the activating mark, H3K4me3. This has been termed as "bivalent chromatin," which is hypothesized as essential to maintain certain ES genes at a low expression level, poised for eventual up-regulation as needed for cell lineage commitment (Bernstein et al. 2006). Indeed, when ES cells are pushed toward neural differentiation in vitro, the expression of several examined genes is increased, the PcG mark is notably reduced, and the active H3K4me3 mark is maintained and/or increased (Bernstein et al. 2006). Such a change is also observed for genes compared be- tween the ES cells and naturally committed cell states (Bernstein et al. 2006). Therefore, a carefully orchestrated, plastic state of gene expression is maintained by PcG proteins and their induced chromatin mark to allow balance between maintenance of stem cell phenotype and cell differentiation during embryonic development.

The chromatin of DNA hypermethylated and silenced cancer may be remarkably similar to the above bivalent chromatin. These genes start with a heritable, silenced state associated with chromatin consisting of highly repressive marks, including mono-, di-, and tri-H3K9me and $\mathrm{H} 3 \mathrm{~K} 27 \mathrm{me}$ and the absence of H3K14 acetylation (McGarvey et al. 2006). As previously discussed, after the induction of DNA demethylation, the chromatin of the re-expressed genes does not fully return to the fully activated state but, rather, active marks are indeed restored while repressive marks, including the PcG related mark, H3K27me, are highly retained (McGarvey et al. 2006).

All of the above perhaps suggest a working model (Fig. 3), wherein during chronic hyperproliferative states that predispose to cancer, such as prolonged inflammation, stem/precursor cells may normally harbor genes marked

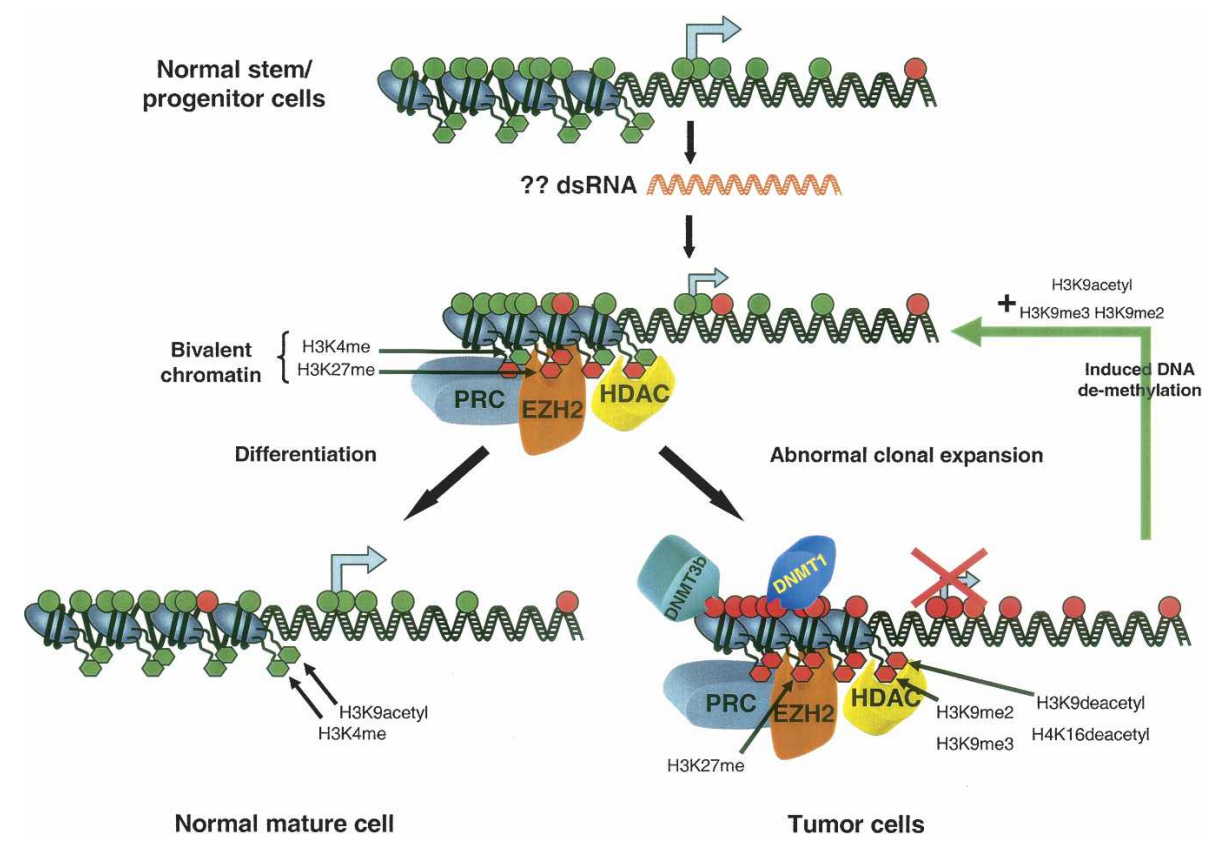

Figure 3. A model for the potential contribution of stem cell chromatin to the initiation and maintenance of aberrant epigenetic gene silencing in cancers. During normal ES cell formation, a bivalent chromatin is recruited to the promoters of a subset of genes that need to be held in a low expression state to prevent lineage commitment. The involvement of small interfering RNA (siRNA) species could be a trigger to this process, and the chromatin is comprised of histone modifications associated with active transcription (H3K4me) and inactive transcription (H3K27me). The PRC are responsible for the H3K27me3 mark through the HMT, EZH2, and deacetylation of key histone lysine residues is catalyzed by HDACs that are recruited by multiple transcriptional repressive complexes. At such genes, DNA is largely unmethylated (green circles), and histones may be maintained in a mixture of acetylated (green hexagons) and deacetylated (red hexagons) states. (Bottom left) With normal cell differentiation and lineage commitment, the genes become transcriptionally active, and the silencing marks are reduced while active histone marks are retained. DNA remains unmethylated. However, as shown in the bottom right, during cancer-predisposing events, abnormal pressure for stem/progenitor cell proliferation with retained bivalent chromatin may allow polycomb proteins and/or marks to recruit other silencing marks such as H3K9me2 and H3K9me3 and DNMTs. The promoter evolves abnormal DNA methylation (red circles) and a tight heritable gene silencing (large red $\mathrm{X}$ ), which results in loss of function for genes. Tumors may arise in such clones with subsequent progression steps. Experimentally, the potential underlying bivalent chromatin for such tumor genes, plus retained H3K9me3, can be revealed by induced DNA demethylation (large green arrow) and resultant gene re-expression. 
by the above bivalent chromatin state. Indeed, many genes on the list of PcG targets in ES cells, such as GATA-4, TIMP 3, and others (Lee et al. 2006), are frequently DNA hypermethylated and silenced in human adult cancers. The repressive marks, particularly H3K27me3 and H3K9me2 and/or H3K9me3, and residence of the PcG proteins may make these promoter regions vulnerable to recruitment of the DNA methylation machinery through mechanisms discussed during this review. Imposition of the DNA methylation on these gene promoters would then convert a low expression state, with a plasticity that would normally allow transcriptional activation during cell maturation, to an epigenetically heritable repressive state. This loss of expression for many developmental and cell maturation genes, including some that would otherwise prevent cell proliferation and would trigger cell senescence or apoptosis, gives the early progenitor cells selective advantage and they would comprise, in essence, tumor stem cells that may participate in neoplastic evolution if the initial clones undergo subsequent tumor progression events. Some of these latter events will clearly be genetic while others may arise through continued evolution of epigenetic abnormalities.

There are certainly more questions inherent in this preliminary model than answers. Nevertheless, the model may help to map out the areas in which profound clues are emerging and help guide where research may be directed. One question is: What initiates the above PcG marking in normal stem/precursor states? Although this will have to be identified, one exciting possibility might be a potential participation by noncoding RNA species (Fig. 3). Participation of such species in triggering transcriptional repression is being incrementally defined especially, from work in plants and yeast (Wassenegger and Pelissier 1998; Pelissier and Wassenegger 2000; Jones et al. 2001; Volpe et al. 2002; Cam and Grewal 2004). Such species, in yeast, can target histone-modifying enzymes, especially those for catalysis of $\mathrm{H} 3 \mathrm{~K} 9$ and $\mathrm{H} 3 \mathrm{~K} 27$, to centrimeric repeat regions (Volpe et al. 2002, 2003; Cam and Grewal 2004). The type I-III HDACs we have discussed could be targeted to remove acetyl groups from histone tails, allowing the HMTs to catalyze the mono-, di-, and trimethyl additions to select lysine residues. HDACs have recently been implicated as critical players in yeast for initial establishment of transcriptional silenced regions (Yamada et al. 2005). Recently, several groups have discovered that small double-stranded RNA (dsRNA) species targeted to gene promoter regions can reproducibly induce transcriptional gene silencing in mammalian cells (Kawasaki and Taira 2004; Morris et al. 2004; Castanotto et al. 2005; Janowski et al. 2005; Ting et al. 2005). This type of silencing is observed with a distinctive increase in histone repressive marks at $\mathrm{H} 3 \mathrm{~K} 9$ and can be alleviated with a coadministration of TSA and 5-aza-2'deoxycytidine (Morris et al. 2004). Whether this dsRNAdependent transcriptional silencing (RdTS) is directly connected to DNA methylation remains to be verified. However, the strong link between RdTS and histone modifications raises the interesting prospect that RdTS may be an endogenous mechanism by which cells establish epigenetic gene regulation. Recently, a report in Drosophila implicates dcr-2, aub, and piwi to be involved in PcG-mediated gene silencing (Grimaud et al. 2006). This point, taken together with the data discussed above, further hints at a possibility that noncoding RNA species and/or RNAi pathways could be important in the process of chromatin-based gene silencing in cancer.

\section{Summary}

While our knowledge of the cancer epigenome is advancing rapidly, much remains to be discovered, and many surprises will surely emerge to enrich our knowledge of basic chromatin function, relationships of adult stem/ precursor cells to normal cell renewal, and of the origins and progression of human cancer. Studies of the cancer epigenome are already beginning to diversify our approaches to cancer control and care and are providing potential molecular marker strategies to assess cancer risk, provide early cancer detection, improve monitoring of cancer prognosis, and predict therapy responses (Herman and Baylin 2003; Laird 2003; Belinsky 2004). Reversal of tumor-associated silencing of tumor suppressor genes is increasingly being targeted for cancer treatment and prevention strategies (Silverman et al. 2002; Issa 2005; Gore et al. 2006). From both basic and clinical research standpoints regarding epigenetics, we have clearly entered a remarkable era of basic and translational studies linking chromatin and cancer research.

\section{Acknowledgments}

We gratefully acknowledge all of our laboratory colleagues whose work contributes to views in this review and for helpful discussions. We also acknowledge all colleagues in general who have so richly built the field of epigenetics. We apologize that not all references could be included.

\section{References}

Aagaard, L., Laible, G., Selenko, P., Schmid, M., Dorn, R., Schotta, G., Kuhfittig, S., Wolf, A., Lebersorger, A., Singh, P.B., et al. 1999. Functional mammalian homologues of the Drosophila PEV-modifier Su(var)3-9 encode centromere-associated proteins which complex with the heterochromatin component M31. EMBO J. 18: 1923-1938.

Aagaard, L., Schmid, M., Warburton, P., and Jenuwein, T. 2000. Mitotic phosphorylation of SUV39H1, a novel component of active centromeres, coincides with transient accumulation at mammalian centromeres. J. Cell Sci. 113: 817-829.

Agoston, A.T., Argani, P., Yegnasubramanian, S., De Marzo, A.M., Ansari-Lari, M.A., Hicks, J.L., Davidson, N.E., and Nelson, W.G. 2005. Increased protein stability causes DNA methyltransferase 1 dysregulation in breast cancer. J. Biol. Chem. 280: 18302-18310.

Akino, K., Toyota, M., Suzuki, H., Mita, H., Sasaki, Y., OheToyota, M., Issa, J.P., Hinoda, Y., Imai, K., and Tokino, T. 2005. The Ras effector RASSF2 is a novel tumor-suppressor gene in human colorectal cancer. Gastroenterology 129: 156-169.

Akiyama, Y., Watkins, N., Suzuki, H., Jair, K.W., van Engeland, M., Esteller, M., Sakai, H., Ren, C.Y., Yuasa, Y., Herman, J.G., et al. 2003. GATA-4 and GATA-5 transcription factor 
genes and potential downstream antitumor target genes are epigenetically silenced in colorectal and gastric cancer. Mol. Cell. Biol. 23: 8429-8439.

Bachman, K.E., Rountree, M.R., and Baylin, S.B. 2001. Dnmt3a and Dnmt3b are transcriptional repressors that exhibit unique localization properties to heterochromatin. J. Biol. Chem. 276: 32282-32287.

Bachman, K.E., Park, B.H., Rhee, I., Rajagopalan, H., Herman, J.G., Baylin, S.B., Kinzler, K.W., and Vogelstein, B. 2003. Histone modifications and silencing prior to DNA methylation of a tumor suppressor gene. Cancer Cell 3: 89-95.

Bachmann, I.M., Halvorsen, O.J., Collett, K., Stefansson, I.M., Straume, O., Haukaas, S.A., Salvesen, H.B., Otte, A.P., and Akslen, L.A. 2006. EZH2 expression is associated with high proliferation rate and aggressive tumor subgroups in cutaneous melanoma and cancers of the endometrium, prostate, and breast. J. Clin. Oncol. 24: 268-273.

Bakin, A.V. and Curran, T. 1999. Role of DNA 5-methylcytosine transferase in cell transformation by fos. Science 283: 387-390.

Bakker, J., Lin, X., and Nelson, W.G. 2002. Methyl-CpG binding domain protein 2 represses transcription from hypermethylated $\pi$-class glutathione $S$-transferase gene promoters in hepatocellular carcinoma cells. J. Biol. Chem. 277: 22573-22580.

Balkwill, F. and Coussens, L.M. 2004. Cancer: An inflammatory link. Nature 431: 405-406.

Ballestar, E. and Esteller, M. 2005. Methyl-CpG-binding proteins in cancer: Blaming the DNA methylation messenger. Biochem. Cell Biol. 83: 374-384.

Bannister, A.J., Schneider, R., and Kouzarides, T. 2002. Histone methylation: Dynamic or static? Cell 109: 801-806.

Bardwell, V.J. and Treisman, R. 1994. The POZ domain: A conserved protein-protein interaction motif. Genes \& Dev. 8: 1664-1677.

Bartolomei, M.S. 2003. Epigenetics: Role of germ cell imprinting. Adv. Exp. Med. Biol. 518: 239-245.

Bartolomei, M.S. and Tilghman, S.M. 1997. Genomic imprinting in mammals. Annu. Rev. Genet. 31: 493-525.

Bartsch, H. and Nair, J. 2005. Accumulation of lipid peroxidation-derived DNA lesions: Potential lead markers for chemoprevention of inflammation-driven malignancies. Mutat. Res. 591: 34-44.

Baylin, S.B. and Ohm, J.E. 2006. Epigenetic gene silencing in cancer-A mechanism for early oncogenic pathway addiction? Nat. Rev. Cancer 6: 107-116.

Beach, R., Chan, A.O., Wu, T.T., White, J.A., Morris, J.S., Lunagomez, S., Broaddus, R.R., Issa, J.P., Hamilton, S.R., and Rashid, A. 2005. BRAF mutations in aberrant crypt foci and hyperplastic polyposis. Am. J. Pathol. 166: 1069-1075.

Belinsky, S.A. 2004. Gene-promoter hypermethylation as a biomarker in lung cancer. Nat. Rev. Cancer 4: 707-717.

Belinsky, S.A., Nikula, K.J., Baylin, S.B., and Issa, J.P. 1996. Increased cytosine DNA-methyltransferase activity is target-cell-specific and an early event in lung cancer. Proc. Nat1. Acad. Sci. 93: 4045-4050.

Belinsky, S.A., Nikula, K.J., Palmisano, W.A., Michels, R., Saccomanno, G., Gabrielson, E., Baylin, S.B., and Herman, J.G. 1998. Aberrant methylation of p16(INK4a) is an early event in lung cancer and a potential biomarker for early diagnosis. Proc. Nat1. Acad. Sci. 95: 11891-11896.

Belinsky, S.A., Klinge, D.M., Stidley, C.A., Issa, J.P., Herman, J.G., March, T.H., and Baylin, S.B. 2003. Inhibition of DNA methylation and histone deacetylation prevents murine lung cancer. Cancer Res. 63: 7089-7093.

Bernstein, B.E., Humphrey, E.L., Erlich, R.L., Schneider, R., Bou- man, P., Liu, J.S., Kouzarides, T., and Schreiber, S.L. 2002. Methylation of histone H3 Lys 4 in coding regions of active genes. Proc. Nat1. Acad. Sci. 99: 8695-8700.

Bernstein, B.E., Kamal, M., Lindblad-Toh, K., Bekiranov, S., Bailey, D.K., Huebert, D.J., McMahon, S., Karlsson, E.K., Kulbokas III, E.J., Gingeras, T.R., et al. 2005. Genomic maps and comparative analysis of histone modifications in human and mouse. Cell 120: 169-181.

Bernstein, B.E., Mikkelsen, T.S., Xie, X., Kamal, M., Huebert, D.J., Cuff, J., Fry, B., Meissner, A., Wernig, M., Plath, K., et al. 2006. A bivalent chromatin structure marks key developmental genes in embryonic stem cells. Cell 125: 315-326.

Bestor, T.H. 1998. The host defence function of genomic methylation patterns. Novartis Found. Symp. 214: 187-195; discussion 195-199, 228-232.

Bird, A. 2002. DNA methylation patterns and epigenetic memory. Genes \& Dev. 16: 6-21.

Bird, A.P. and Wolffe, A.P. 1999. Methylation-induced repression-Belts, braces, and chromatin. Cell 99: 451-454.

Bjerkvig, R., Tysnes, B.B., Aboody, K.S., Najbauer, J., and Terzis, A.J. 2005. Opinion: The origin of the cancer stem cell: Current controversies and new insights. Nat. Rev. Cancer 5: 899-904.

Boyer, L.A., Plath, K., Zeitlinger, J., Brambrink, T., Medeiros, L.A., Lee, T.I., Levine, S.S., Wernig, M., Tajonar, A., Ray, M.K., et al. 2006. Polycomb complexes repress developmental regulators in murine embryonic stem cells. Nature 441: 349-353.

Bracken, A.P., Pasini, D., Capra, M., Prosperini, E., Colli, E., and Helin, K. 2003. EZH2 is downstream of the pRB-E2F pathway, essential for proliferation and amplified in cancer. EMBO T. 22: 5323-5335.

Briggs, S.D., Xiao, T., Sun, Z.W., Caldwell, J.A., Shabanowitz, J., Hunt, D.F., Allis, C.D., and Strahl, B.D. 2002. Gene silencing: Trans-histone regulatory pathway in chromatin. Nature 418: 498.

Bruggeman, S.W., Valk-Lingbeek, M.E., van der Stoop, P.P., Jacobs, J.J., Kieboom, K., Tanger, E., Hulsman, D., Leung, C., Arsenijevic, Y., Marino, S., et al. 2005. Ink4a and Arf differentially affect cell proliferation and neural stem cell selfrenewal in Bmil-deficient mice. Genes \& Dev. 19: 14381443.

Burgers, W.A., Fuks, F., and Kouzarides, T. 2002. DNA methyltransferases get connected to chromatin. Trends Genet. 18: 275-277.

Cam, H. and Grewal, S.I. 2004. RNA interference and epigenetic control of heterochromatin assembly in fission yeast. Cold Spring Harb. Symp. Quant. Biol. 69: 419-427.

Cameron, E.E., Bachman, K.E., Myohanen, S., Herman, J.G., and Baylin, S.B. 1999. Synergy of demethylation and histone deacetylase inhibition in the re-expression of genes silenced in cancer. Nat. Genet. 21: 103-107.

Carter, M.G., Johns, M.A., Zeng, X., Zhou, L., Zink, M.C., Mankowski, J.L., Donovan, D.M., and Baylin, S.B. 2000. Mice deficient in the candidate tumor suppressor gene Hic1 exhibit developmental defects of structures affected in the Miller-Dieker syndrome. Hum. Mol. Genet. 9: 413-419.

Castanotto, D., Tommasi, S., Li, M., Li, H., Yanow, S., Pfeifer, G.P., and Rossi, J.J. 2005. Short hairpin RNA-directed cytosine (CpG) methylation of the RASSF1A gene promoter in HeLa cells. Mol. Ther. 12: 179-183.

Chen, W.Y., Zeng, X., Carter, M.G., Morrell, C.N., Chiu Yen, R.W., Esteller, M., Watkins, D.N., Herman, J.G., Mankowski, J.L., and Baylin, S.B. 2003. Heterozygous disruption of Hicl predisposes mice to a gender-dependent spectrum of malignant tumors. Nat. Genet. 33: 197-202. 
Chen, W., Cooper, T.K., Zahnow, C.A., Overholtzer, M., Zhao, Z., Ladanyi, M., Karp, J.E., Gokgoz, N., Wunder, J.S., Andrulis, I.L., et al. 2004. Epigenetic and genetic loss of Hicl function accentuates the role of p53 in tumorigenesis. Cancer Cell 6: 387-398.

Chen, W.Y., Wang, D.H., Yen, R.C., Luo, J., Gu, W., and Baylin, S.B. 2005. Tumor suppressor HIC1 directly regulates SIRT1 to modulate p53-dependent DNA-damage responses. Cell 123: 437-448.

Chin, H.G., Patnaik, D., Esteve, P.O., Jacobsen, S.E., and Pradhan, S. 2006. Catalytic properties and kinetic mechanism of human recombinant Lys-9 histone $\mathrm{H} 3$ methyltransferase SUV39H1: Participation of the chromodomain in enzymatic catalysis. Biochemistry 45: 3272-3284.

Chopra, V.S. and Mishra, R.K. 2005. To SIR with Polycomb: Linking silencing mechanisms. Bioessays 27: 119-121.

Coussens, L.M. and Werb, Z. 2002. Inflammation and cancer. Nature 420: 860-867.

Cui, H., Cruz-Correa, M., Giardiello, F.M., Hutcheon, D.F., Kafonek, D.R., Brandenburg, S., Wu, Y., He, X., Powe, N.R., and Feinberg, A.P. 2003. Loss of IGF2 imprinting: A potential marker of colorectal cancer risk. Science 299: 1753-1755.

Czermin, B., Melfi, R., McCabe, D., Seitz, V., Imhof, A., and Pirrotta, V. 2002. Drosophila enhancer of Zeste/ESC complexes have a histone $\mathrm{H} 3$ methyltransferase activity that marks chromosomal Polycomb sites. Cell 111: 185-196.

Darwanto, A., Kitazawa, R., Maeda, S., and Kitazawa, S. 2003. $\mathrm{MeCP} 2$ and promoter methylation cooperatively regulate Ecadherin gene expression in colorectal carcinoma. Cancer Sci. 94: 442-447.

Datta, J., Ghoshal, K., Sharma, S.M., Tajima, S., and Jacob, S.T. 2003. Biochemical fractionation reveals association of DNA methyltransferase (Dnmt) 3b with Dnmt1 and that of Dnmt $3 \mathrm{a}$ with a histone $\mathrm{H} 3$ methyltransferase and Hdac1. J. Cell. Biochem. 88: 855-864.

De Marzo, A.M., Marchi, V.L., Yang, E.S., Veeraswamy, R., Lin, X., and Nelson, W.G. 1999. Abnormal regulation of DNA methyltransferase expression during colorectal carcinogenesis. Cancer Res. 59: 3855-3860.

Di Croce, L., Raker, V.A., Corsaro, M., Fazi, F., Fanelli, M. Faretta, M., Fuks, F., Lo Coco, F., Kouzarides, T., Nervi, C., et al. 2002. Methyltransferase recruitment and DNA hypermethylation of target promoters by an oncogenic transcription factor. Science 295: 1079-1082.

Ebert, A., Schotta, G., Lein, S., Kubicek, S., Krauss, V., Jenuwein, T., and Reuter, G. 2004. Su(var) genes regulate the balance between euchromatin and heterochromatin in Drosophila. Genes \& Dev. 18: 2973-2983.

Egger, G., Jeong, S., Escobar, S.G., Cortez, C.C., Li, T.W., Saito, Y., Yoo, C.B., Jones, P.A., and Liang, G. 2006. Identification of DNMT1 (DNA methyltransferase 1) hypomorphs in somatic knockouts suggests an essential role for DNMT1 in cell survival. Proc. Natl. Acad. Sci. 103: 14080-14085.

Eguchi, K., Kanai, Y., Kobayashi, K., and Hirohashi, S. 1997. DNA hypermethylation at the D17S5 locus in non-small cell lung cancers: Its association with smoking history. Cancer Res. 57: 4913-4915.

El-Osta, A., Kantharidis, P., Zalcberg, J.R., and Wolffe, A.P. 2002. Precipitous release of methyl-CpG binding protein 2 and histone deacetylase 1 from the methylated human multidrug resistance gene (MDR1) on activation. Mol. Cell. Biol. 22: $1844-1857$.

Espada, J., Ballestar, E., Fraga, M.F., Villar-Garea, A., Juarranz, A., Stockert, J.C., Robertson, K.D., Fuks, F., and Esteller, M. 2004. Human DNA methyltransferase 1 is required for maintenance of the histone $\mathrm{H} 3$ modification pattern. J. Biol.
Chem. 279: 37175-37184.

Esteller, M., Silva, J.M., Dominguez, G., Bonilla, F., MatiasGuiu, X., Lerma, E., Bussaglia, E., Prat, J., Harkes, I.C., Repasky, E.A., et al. 2000a. Promoter hypermethylation and BRCA1 inactivation in sporadic breast and ovarian tumors. J. Nat1. Cancer Inst. 92: 564-569.

Esteller, M., Sparks, A., Toyota, M., Sanchez-Cespedes, M., Capella, G., Peinado, M.A., Gonzalez, S., Tarafa, G., Sidransky, D., Meltzer, S.J., et al. 2000b. Analysis of adenomatous polyposis coli promoter hypermethylation in human cancer. Cancer Res. 60: 4366-4371.

Etoh, T., Kanai, Y., Ushijima, S., Nakagawa, T., Nakanishi, Y., Sasako, M., Kitano, S., and Hirohashi, S. 2004. Increased DNA methyltransferase 1 (DNMT1) protein expression correlates significantly with poorer tumor differentiation and frequent DNA hypermethylation of multiple CpG islands in gastric cancers. Am. J. Pathol. 164: 689-699.

Fahrner, J.A., Eguchi, S., Herman, J.G., and Baylin, S.B. 2002. Dependence of histone modifications and gene expression on DNA hypermethylation in cancer. Cancer Res. 62: 72137218.

Feinberg, A.P. 2005. Cancer epigenetics is no Mickey Mouse. Cancer Cell 8: 267-268.

Feinberg, A.P. and Tycko, B. 2004. The history of cancer epigenetics. Nat. Rev. Cancer 4: 143-153.

Feinberg, A.P. and Vogelstein, B. 1983. Hypomethylation distinguishes genes of some human cancers from their normal counterparts. Nature 301: 89-92.

Feinberg, A.P., Gehrke, C.W., Kuo, K.C., and Ehrlich, M. 1988 Reduced genomic 5-methylcytosine content in human colonic neoplasia. Cancer Res. 48: 1159-1161.

Feinberg, A.P., Ohlsson, R., and Henikoff, S. 2006. The epigenetic progenitor origin of human cancer. Nat. Rev. Genet. 7: 21-33.

Ferguson-Smith, A.C. and Surani, M.A. 2001. Imprinting and the epigenetic asymmetry between parental genomes. Science 293: 1086-1089.

Finch, P.W., He, X., Kelley, M.J., Uren, A., Schaudies, R.P., Popescu, N.C., Rudikoff, S., Aaronson, S.A., Varmus, H.E., and Rubin, J.S. 1997. Purification and molecular cloning of a secreted, Frizzled-related antagonist of Wnt action. Proc. Natl. Acad. Sci. 94: 6770-6775.

Fodde, R., Smits, R., and Clevers, H. 2001. APC, signal transduction and genetic instability in colorectal cancer. Nat. Rev. Cancer 1: 55-67.

Fodor, B.D., Kubicek, S., Yonezawa, M., O'Sullivan, J., Sengupta, R., Perez-Burgos, L., Opravil, S., Mechtler, K., Schotta, G., and Jenuwein, T. 2006. Jmjd2b antagonizes H3K9 trimethylation at pericentric heterochromatin in mammalian cells. Genes \& Dev. 20: 1557-1562.

Forneris, F., Binda, C., Vanoni, M.A., Mattevi, A., and Battaglioli, E. 2005. Histone demethylation catalysed by LSD1 is a flavin-dependent oxidative process. FEBS Lett. 579: 22032207.

Foster, S.A., Wong, D.J., Barrett, M.T., and Galloway, D.A. 1998. Inactivation of p16 in human mammary epithelial cells by CpG island methylation. Mol. Cell. Biol. 18: 17931801.

Fraga, M.F., Ballestar, E., Villar-Garea, A., Boix-Chornet, M., Espada, J., Schotta, G., Bonaldi, T., Haydon, C., Ropero, S., Petrie, K., et al. 2005. Loss of acetylation at Lys16 and trimethylation at Lys20 of histone $\mathrm{H} 4$ is a common hallmark of human cancer. Nat. Genet. 37: 391-400.

Frigola, J., Song, J., Stirzaker, C., Hinshelwood, R.A., Peinado, M.A., and Clark, S.J. 2006. Epigenetic remodeling in colorectal cancer results in coordinate gene suppression across 
an entire chromosome band. Nat. Genet. 38: 540-549.

Fujii, H., Biel, M.A., Zhou, W., Weitzman, S.A., Baylin, S.B., and Gabrielson, E. 1998. Methylation of the HIC-1 candidate tumor suppressor gene in human breast cancer. Oncogene 16: $2159-2164$

Fuks, F., Burgers, W.A., Godin, N., Kasai, M., and Kouzarides, T. 2001. Dnmt3a binds deacetylases and is recruited by a sequence-specific repressor to silence transcription. EMBO J. 20: $2536-2544$

Furuyama, T., Banerjee, R., Breen, T.R., and Harte, P.J. 2004. SIR2 is required for polycomb silencing and is associated with an E(Z) histone methyltransferase complex. Curr. Biol. 14: 1812-1821.

Ghoshal, K., Datta, J., Majumder, S., Bai, S., Dong, X., Parthun, M., and Jacob, S.T. 2002. Inhibitors of histone deacetylase and DNA methyltransferase synergistically activate the methylated metallothionein I promoter by activating the transcription factor MTF-1 and forming an open chromatin structure. Mol. Cell. Biol. 22: 8302-8319.

Gibbons, R.J. 2005. Histone modifying and chromatin remodelling enzymes in cancer and dysplastic syndromes. Hum. Mol. Genet. 14: R85-R92.

Gore, S.D., Baylin, S., Sugar, E., Carraway, H., Miller, C.B., Carducci, M., Grever, M., Galm, O., Dauses, T., Karp, J.E., et al. 2006. Combined DNA methyltransferase and histone deacetylase inhibition in the treatment of myeloid neoplasms. Cancer Res. 66: 6361-6369.

Gregorieff, A. and Clevers, H. 2005. Wnt signaling in the intestinal epithelium: From endoderm to cancer. Genes \& Dev. 19: $877-890$.

Grimaud, C., Bantignies, F., Pal-Bhadra, M., Ghana, P., Bhadra, U., and Cavalli, G. 2006. RNAi components are required for nuclear clustering of Polycomb group response elements. Cell 124: 957-971.

Gruenbaum, Y., Cedar, H., and Razin, A. 1982. Substrate and sequence specificity of a eukaryotic DNA methylase. Nature 295: 620-622.

Guarente, L. 2000. Sir2 links chromatin silencing, metabolism, and aging. Genes \& Dev. 14: 1021-1026.

Guerardel, C., Deltour, S., Pinte, S., Monte, D., Begue, A., Godwin, A.K., and Leprince, D. 2001. Identification in the human candidate tumor suppressor gene HIC-1 of a new major alternative TATA-less promoter positively regulated by $\mathrm{p} 53$. J. Biol. Chem. 276: 3078-3089.

Hanahan, D. and Weinberg, R.A. 2000. The hallmarks of cancer. Cell 100: $57-70$.

Hayashi, M., Tokuchi, Y., Hashimoto, T., Hayashi, S., Nishida, K., Ishikawa, Y., Nakagawa, K., Tsuchiya, S., Okumura, S., and Tsuchiya, E. 2001. Reduced HIC-1 gene expression in non-small cell lung cancer and its clinical significance. Anticancer Res. 21: 535-540.

Hedenfalk, I., Duggan, D., Chen, Y., Radmacher, M., Bittner, M., Simon, R., Meltzer, P., Gusterson, B., Esteller, M., Kallioniemi, O.P., et al. 2001. Gene-expression profiles in hereditary breast cancer. N. Engl. J. Med. 344: 539-548.

Herman, J.G. and Baylin, S.B. 2003. Gene silencing in cancer in association with promoter hypermethylation. N. Engl. J. Med. 349: 2042-2054.

Herman, J.G., Latif, F., Weng, Y., Lerman, M.I., Zbar, B., Liu, S., Samid, D., Duan, D.S., Gnarra, J.R., Linehan, W.M., et al. 1994. Silencing of the VHL tumor-suppressor gene by DNA methylation in renal carcinoma. Proc. Natl. Acad. Sci. 91: 9700-9704.

Hernandez-Munoz, I., Taghavi, P., Kuijl, C., Neefjes, J., and van Lohuizen, M. 2005. Association of BMI1 with polycomb bodies is dynamic and requires PRC2/EZH2 and the mainte- nance DNA methyltransferase DNMT1. Mol. Cell. Biol. 25: 11047-11058.

Hochedlinger, K., Yamada, Y., Beard, C., and Jaenisch, R. 2005. Ectopic expression of Oct-4 blocks progenitor-cell differentiation and causes dysplasia in epithelial tissues. Cell 121: 465-477.

Holm, T.M., Jackson-Grusby, L., Brambrink, T., Yamada, Y., Rideout III, W.M., and Jaenisch, R. 2005. Global loss of imprinting leads to widespread tumorigenesis in adult mice. Cancer Cell 8: 275-285.

Howitz, K.T., Bitterman, K.J., Cohen, H.Y., Lamming, D.W., Lavu, S., Wood, J.G., Zipkin, R.E., Chung, P., Kisielewski, A., Zhang, L.L., et al. 2003. Small molecule activators of sirtuins extend Saccharomyces cerevisiae lifespan. Nature 425: 191196.

Issa, J.P. 2004. CpG island methylator phenotype in cancer. Nat. Rev. Cancer 4: 988-993.

Issa, J.P. 2005. Optimizing therapy with methylation inhibitors in myelodysplastic syndromes: Dose, duration, and patient selection. Nat. Clin. Pract. Oncol. 2 (Suppl. 1): S24-S29.

Issa, J.P., Vertino, P.M., Wu, J., Sazawal, S., Celano, P., Nelkin, B.D., Hamilton, S.R., and Baylin, S.B. 1993. Increased cytosine DNA-methyltransferase activity during colon cancer progression. J. Natl. Cancer Inst. 85: 1235-1240.

Jackson, J.P., Lindroth, A.M., Cao, X., and Jacobsen, S.E. 2002. Control of CpNpG DNA methylation by the KRYPTONITE histone H3 methyltransferase. Nature 416: 556-560.

Jackson, J.P., Johnson, L., Jasencakova, Z., Zhang, X., PerezBurgos, L., Singh, P.B., Cheng, X., Schubert, I., Jenuwein, T., and Jacobsen, S.E. 2004. Dimethylation of histone H3 lysine 9 is a critical mark for DNA methylation and gene silencing in Arabidopsis thaliana. Chromosoma 112: 308-315.

Jacobs, S.A., Taverna, S.D., Zhang, Y., Briggs, S.D., Li, J., Eissenberg, J.C., Allis, C.D., and Khorasanizadeh, S. 2001. Specificity of the HP1 chromo domain for the methylated $\mathrm{N}$-terminus of histone H3. EMBO J. 20: 5232-5241.

Jair, K.W., Bachman, K.E., Suzuki, H., Ting, A.H., Rhee, I., Yen, R.W., Baylin, S.B., and Schuebel, K.E. 2006. De novo CpG island methylation in human cancer cells. Cancer Res. 66: 682-692.

Janowski, B.A., Huffman, K.E., Schwartz, J.C., Ram, R., Hardy, D., Shames, D.S., Minna, J.D., and Corey, D.R. 2005. Inhibiting gene expression at transcription start sites in chromosomal DNA with antigene RNAs. Nat. Chem. Biol. 1: 216222.

Janzen, V., Forkert, R., Fleming, H.E., Saito, Y., Waring, M.T., Dombkowski, D.M., Cheng, T., DePinho, R.A., Sharpless, N.E., and Scadden, D.T. 2006. Stem-cell ageing modified by the cyclin-dependent kinase inhibitor p16(INK4a). Nature 443: 421-426.

Jenuwein, T. and Allis, C.D. 2001. Translating the histone code. Science 293: 1074-1080.

Johnson, L., Cao, X., and Jacobsen, S. 2002. Interplay between two epigenetic marks. DNA methylation and histone $\mathrm{H} 3$ lysine 9 methylation. Curr. Biol. 12: 1360-1367.

Jones, P.A. and Baylin, S.B. 2002. The fundamental role of epigenetic events in cancer. Nat. Rev. Genet. 3: 415-428.

Jones, P.A. and Laird, P.W. 1999. Cancer epigenetics comes of age. Nat. Genet. 21: 163-167.

Jones, L., Ratcliff, F., and Baulcombe, D.C. 2001. RNA-directed transcriptional gene silencing in plants can be inherited independently of the RNA trigger and requires Met1 for maintenance. Curr. Biol. 11: 747-757.

Kaeberlein, M., McVey, M., and Guarente, L. 1999. The SIR2/ $3 / 4$ complex and SIR2 alone promote longevity in Saccharomyces cerevisiae by two different mechanisms. Genes \& 
Dev. 13: 2570-2580.

Kaneda, A. and Feinberg, A.P. 2005. Loss of imprinting of IGF2: A common epigenetic modifier of intestinal tumor risk. Cancer Res. 65: 11236-11240.

Kato, Y. and Sasaki, H. 2005. Imprinting and looping: Epigenetic marks control interactions between regulatory elements. Bioessays 27: 1-4.

Kawasaki, H. and Taira, K. 2004. Induction of DNA methylation and gene silencing by short interfering RNAs in human cells. Nature 431: 211-217.

Kim, G.D., Ni, J., Kelesoglu, N., Roberts, R.J., and Pradhan, S. 2002. Co-operation and communication between the human maintenance and de novo DNA (cytosine-5) methyltransferases. EMBO J. 21: 4183-4195.

Kimura, A., Umehara, T., and Horikoshi, M. 2002. Chromosomal gradient of histone acetylation established by Sas $2 p$ and Sir2p functions as a shield against gene silencing. Nat. Genet. 32: 370-377.

Kinzler, K.W. and Vogelstein, B. 1996. Lessons from hereditary colorectal cancer. Cell 87: 159-170.

Kirmizis, A., Bartley, S.M., and Farnham, P.J. 2003. Identification of the polycomb group protein $\mathrm{SU}(\mathrm{Z}) 12$ as a potential molecular target for human cancer therapy. Mol. Cancer Ther. 2: 113-121.

Kirmizis, A., Bartley, S.M., Kuzmichev, A., Margueron, R., Reinberg, D., Green, R., and Farnham, P.J. 2004. Silencing of human polycomb target genes is associated with methylation of histone H3 Lys 27. Genes \& Dev. 18: 1592-1605.

Kiyono, T., Foster, S.A., Koop, J.I., McDougall, J.K., Galloway, D.A., and Klingelhutz, A.J. 1998. Both Rb/p16INK4a inactivation and telomerase activity are required to immortalize human epithelial cells. Nature 396: 84-88.

Kleer, C.G., Cao, Q., Varambally, S., Shen, R., Ota, I., Tomlins, S.A., Ghosh, D., Sewalt, R.G., Otte, A.P., Hayes, D.F., et al. 2003. EZH2 is a marker of aggressive breast cancer and promotes neoplastic transformation of breast epithelial cells. Proc. Natl. Acad. Sci. 100: 11606-11611.

Koizume, S., Tachibana, K., Sekiya, T., Hirohashi, S., and Shiraishi, M. 2002. Heterogeneity in the modification and involvement of chromatin components of the CpG island of the silenced human CDH1 gene in cancer cells. Nucleic Acids Res. 30: 4770-4780.

Kondo, Y. and Issa, J.P. 2004. Epigenetic changes in colorectal cancer. Cancer Metastasis Rev. 23: 29-39.

Kondo, Y., Shen, L., and Issa, J.P. 2003. Critical role of histone methylation in tumor suppressor gene silencing in colorectal cancer. Mol. Cell. Biol. 23: 206-215.

Krishnamurthy, J., Ramsey, M.R., Ligon, K.L., Torrice, C., Koh, A., Bonner-Weir, S., and Sharpless, N.E. 2006. p16(INK4a) induces an age-dependent decline in islet regenerative potential. Nature 443: 453-457.

Krouwels, I.M., Wiesmeijer, K., Abraham, T.E., Molenaar, C. Verwoerd, N.P., Tanke, H.J., and Dirks, R.W. 2005. A glue for heterochromatin maintenance: Stable SUV39H1 binding to heterochromatin is reinforced by the SET domain. J. Cell Biol. 170: 537-549.

Kuzmichev, A., Jenuwein, T., Tempst, P., and Reinberg, D. 2004. Different EZH2-containing complexes target methylation of histone $\mathrm{H} 1$ or nucleosomal histone H3. Mol. Cell 14: 183-193.

Kuzmichev, A., Margueron, R., Vaquero, A., Preissner, T.S., Scher, M., Kirmizis, A., Ouyang, X., Brockdorff, N., AbateShen, C., Farnham, P., et al. 2005. Composition and histone substrates of polycomb repressive group complexes change during cellular differentiation. Proc. Natl. Acad. Sci. 102: 1859-1864.
Lacher, M.D., Siegenthaler, A., Jager, R., Yan, X., Hett, S., Xuan, L., Saurer, S., Lareu, R.R., Dharmarajan, A.M., and Friis, R. 2003. Role of DDC-4/sFRP-4, a secreted Frizzled-related protein, at the onset of apoptosis in mammary involution. Cell Death Differ. 10: 528-538.

Lachner, M. and Jenuwein, T. 2002. The many faces of histone lysine methylation. Curr. Opin. Cell Biol. 14: 286-298.

Lachner, M., O'Sullivan, R.J., and Jenuwein, T. 2003. An epigenetic road map for histone lysine methylation. J. Cell Sci. 116: 2117-2124.

Lachner, M., Sengupta, R., Schotta, G., and Jenuwein, T. 2004. Trilogies of histone lysine methylation as epigenetic landmarks of the eukaryotic genome. Cold Spring Harb. Symp. Quant. Biol. 69: 209-218.

Laird, P.W. 2003. The power and the promise of DNA methylation markers. Nat. Rev. Cancer 3: 253-266.

Langley, E., Pearson, M., Faretta, M., Bauer, U.M., Frye, R.A., Minucci, S., Pelicci, P.G., and Kouzarides, T. 2002. Human SIR2 deacetylates p53 and antagonizes PML/p53-induced cellular senescence. EMBO T. 21: 2383-2396.

Lee, T.I., Jenner, R.G., Boyer, L.A., Guenther, M.G., Levine, S.S., Kumar, R.M., Chevalier, B., Johnstone, S.E., Cole, M.F., Isono, K., et al. 2006. Control of developmental regulators by polycomb in human embryonic stem cells. Cell 125: 301313.

Lehnertz, B., Ueda, Y., Derijck, A.A., Braunschweig, U., PerezBurgos, L., Kubicek, S., Chen, T., Li, E., Jenuwein, T., and Peters, A.H. 2003. Suv39h-mediated histone H3 lysine 9 methylation directs DNA methylation to major satellite repeats at pericentric heterochromatin. Curr. Biol. 13: 11921200.

Lei, H., Oh, S.P., Okano, M., Juttermann, R., Goss, K.A., Jaenisch, R., and Li, E. 1996. De novo DNA cytosine methyltransferase activities in mouse embryonic stem cells. Development 122: 3195-3205.

Lessard, J., Schumacher, A., Thorsteinsdottir, U., van Lohuizen, M., Magnuson, T., and Sauvageau, G. 1999. Functional antagonism of the Polycomb-Group genes eed and Bmil in hemopoietic cell proliferation. Genes \& Dev. 13: 2691-2703.

Leung, C., Lingbeek, M., Shakhova, O., Liu, J., Tanger, E., Saremaslani, P., Van Lohuizen, M., and Marino, S. 2004. Bmil is essential for cerebellar development and is overexpressed in human medulloblastomas. Nature 428: 337-341.

Li, E., Bestor, T.H., and Jaenisch, R. 1992. Targeted mutation of the DNA methyltransferase gene results in embryonic lethality. Cell 69: 915-926.

Lin, S.J., Defossez, P.A., and Guarente, L. 2000. Requirement of NAD and SIR2 for life-span extension by calorie restriction in Saccharomyces cerevisiae. Science 289: 2126-2128.

Lu, H., Ouyang, W., and Huang, C. 2006. Inflammation, a key event in cancer development. Mol. Cancer Res. 4: 221-233.

Lund, A. and van Lohuizen, M. 2004a. Polycomb complexes and silencing mechanisms. Curr. Opin. Genet. Dev. 16: 239-246.

Lund, A.H. and van Lohuizen, M. 2004b. Epigenetics and cancer. Genes \& Dev. 18: 2315-2335.

Luo, J., Nikolaev, A.Y., Imai, S., Chen, D., Su, F., Shiloh, A., Guarente, L., and Gu, W. 2001. Negative control of p53 by Sir2 $\alpha$ promotes cell survival under stress. Cell 107: 137-148.

Lyko, F., Ramsahoye, B.H., Kashevsky, H., Tudor, M., Mastrangelo, M.A., Orr-Weaver, T.L., and Jaenisch, R. 1999. Mammalian (cytosine-5) methyltransferases cause genomic DNA methylation and lethality in Drosophila. Nat. Genet. 23: 363-366.

Maison, C., Bailly, D., Peters, A.H., Quivy, J.P., Roche, D., Taddei, A., Lachner, M., Jenuwein, T., and Almouzni, G. 2002. Higher-order structure in pericentric heterochromatin in- 
volves a distinct pattern of histone modification and an RNA component. Nat. Genet. 30: 329-334.

Matsukawa, Y., Semba, S., Kato, H., Ito, A., Yanagihara, K., and Yokozaki, H. 2006. Expression of the enhancer of zeste homolog 2 is correlated with poor prognosis in human gastric cancer. Cancer Sci. 97: 484-491.

McGarvey, K.M., Fahrner, J.A., Greene, E., Martens, J., Jenuwein, T., and Baylin, S.B. 2006. Silenced tumor suppressor genes reactivated by DNA demethylation do not return to a fully euchromatic chromatin state. Cancer Res. 66: 35413549.

Melcher, M., Schmid, M., Aagaard, L., Selenko, P., Laible, G., and Jenuwein, T. 2000. Structure-function analysis of SUV39H1 reveals a dominant role in heterochromatin organization, chromosome segregation, and mitotic progression. Mol. Cell. Biol. 20: 3728-3741.

Melki, J.R., Warnecke, P., Vincent, P.C., and Clark, S.J. 1998. Increased DNA methyltransferase expression in leukaemia. Leukemia 12: 311-316.

Metzger, E., Wissmann, M., Yin, N., Muller, J.M., Schneider, R., Peters, A.H., Gunther, T., Buettner, R., and Schule, R. 2005. LSD1 demethylates repressive histone marks to promote androgen-receptor-dependent transcription. Nature 437: 436439.

Molofsky, A.V., Slutsky, S.G., Joseph, N.M., He, S., Pardal, R., Krishnamurthy, J., Sharpless, N.E., and Morrison, S.J. 2006. Increasing p16(INK4a) expression decreases forebrain progenitors and neurogenesis during ageing. Nature 443: 448452.

Morin, P.J., Sparks, A.B., Korinek, V., Barker, N., Clevers, H., Vogelstein, B., and Kinzler, K.W. 1997. Activation of $\beta$-catenin-Tcf signaling in colon cancer by mutations in $\beta$-catenin or APC. Science 275: 1787-1790.

Morris, K.V., Chan, S.W., Jacobsen, S.E., and Looney, D.J. 2004. Small interfering RNA-induced transcriptional gene silencing in human cells. Science 305: 1289-1292.

Muller, H.M., Fiegl, H., Goebel, G., Hubalek, M.M., Widschwendter, A., Muller-Holzner, E., Marth, C., and Widschwendter, M. 2003. MeCP2 and MBD2 expression in human neoplastic and non-neoplastic breast tissue and its association with oestrogen receptor status. Br. J. Cancer 89: 19341939.

Muyrers-Chen, I., Hernandez-Munoz, I., Lund, A.H., Valk-Lingbeek, M.E., van der Stoop, P., Boutsma, E., Tolhuis, B., Bruggeman, S.W., Taghavi, P., Verhoeven, E., et al. 2004. Emerging roles of Polycomb silencing in X-inactivation and stem cell maintenance. Cold Spring Harb. Symp. Quant. Biol. 69: 319-326.

Nagata, M. 2005. Inflammatory cells and oxygen radicals. Curr. Drug Targets Inflamm. Allergy 4: 503-504.

Narayan, A., Ji, W., Zhang, X.Y., Marrogi, A., Graff, J.R., Baylin, S.B., and Ehrlich, M. 1998. Hypomethylation of pericentromeric DNA in breast adenocarcinomas. Int. I. Cancer 77: 833-838.

Nelson, W.G., De Marzo, A.M., DeWeese, T.L., and Isaacs, W.B. 2004. The role of inflammation in the pathogenesis of prostate cancer. J. Urol. 172: S6-S11. discussion S11-S12

Nguyen, C.T., Gonzales, F.A., and Jones, P.A. 2001. Altered chromatin structure associated with methylation-induced gene silencing in cancer cells: Correlation of accessibility, methylation, MeCP2 binding and acetylation. Nucleic Acids Res. 29: 4598-4606.

Nguyen, C.T., Weisenberger, D.J., Velicescu, M., Gonzales, F.A., Lin, J.C., Liang, G., and Jones, P.A. 2002. Histone H3lysine 9 methylation is associated with aberrant gene silencing in cancer cells and is rapidly reversed by 5 -aza-2'-deoxy- cytidine. Cancer Res. 62: 6456-6461.

Nielsen, S.J., Schneider, R., Bauer, U.M., Bannister, A.J., Morrison, A., O'Carroll, D., Firestein, R., Cleary, M., Jenuwein, T., Herrera, R.E., et al. 2001. Rb targets histone $\mathrm{H} 3$ methylation and HP1 to promoters. Nature 412: 561-565.

Nuovo, G.J., Plaia, T.W., Belinsky, S.A., Baylin, S.B., and Herman, J.G. 1999. In situ detection of the hypermethylationinduced inactivation of the p16 gene as an early event in oncogenesis. Proc. Natl. Acad. Sci. 96: 12754-12759.

Okano, M., Bell, D.W., Haber, D.A., and Li, E. 1999. DNA methyltransferases Dnmt3a and Dnmt3b are essential for de novo methylation and mammalian development. Cell 99: 247257.

Orlando, V. 2003. Polycomb, epigenomes, and control of cell identity. Cell 112: 599-606.

Paz, M.F., Wei, S., Cigudosa, J.C., Rodriguez-Perales, S., Peinado, M.A., Huang, T.H., and Esteller, M. 2003. Genetic unmasking of epigenetically silenced tumor suppressor genes in colon cancer cells deficient in DNA methyltransferases. Hum. Mol. Genet. 12: 2209-2219.

Pedrali-Noy, G. and Weissbach, A. 1986. Mammalian DNA methyltransferases prefer poly(dI-dC) as substrate. J. Biol. Chem. 261: 7600-7602.

Pelissier, T. and Wassenegger, M. 2000. A DNA target of $30 \mathrm{bp}$ is sufficient for RNA-directed DNA methylation. RNA 6: $55-65$.

Peters, A.H., O'Carroll, D., Scherthan, H., Mechtler, K., Sauer, S., Schofer, C., Weipoltshammer, K., Pagani, M., Lachner, M., Kohlmaier, A., et al. 2001. Loss of the Suv39h histone methyltransferases impairs mammalian heterochromatin and genome stability. Cell 107: 323-337.

Pirrotta, V. and Gross, D.S. 2005. Epigenetic silencing mechanisms in budding yeast and fruit fly: Different paths, same destinations. Mol. Cell 18: 395-398.

Plath, K., Fang, J., Mlynarczyk-Evans, S.K., Cao, R., Worringer, K.A., Wang, H., de la Cruz, C.C., Otte, A.P., Panning, B., and Zhang, Y. 2003. Role of histone H3 lysine 27 methylation in $\mathrm{X}$ inactivation. Science 300: 131-135.

Pruitt, K., Zinn, R.L., Ohm, J.E., McGarvey, K.M., Kang, S.H., Watkins, D.N., Herman, J.G., and Baylin, S.B. 2006. Inhibition of SIRT1 reactivates silenced cancer genes without loss of promoter DNA hypermethylation. PLoS Genet. 2: 344352 .

Radtke, F. and Clevers, H. 2005. Self-renewal and cancer of the gut: Two sides of a coin. Science 307: 1904-1909.

Ramsahoye, B.H., Biniszkiewicz, D., Lyko, F., Clark, V., Bird, A.P., and Jaenisch, R. 2000. Non-CpG methylation is prevalent in embryonic stem cells and may be mediated by DNA methyltransferase 3a. Proc. Natl. Acad. Sci. 97: 5237-5242.

Rattner, A., Hsieh, J.C., Smallwood, P.M., Gilbert, D.J., Copeland, N.G., Jenkins, N.A., and Nathans, J. 1997. A family of secreted proteins contains homology to the cysteine-rich ligand-binding domain of frizzled receptors. Proc. Natl. Acad. Sci. 94: 2859-2863.

Rea, S., Eisenhaber, F., O'Carroll, D., Strahl, B.D., Sun, Z.W., Schmid, M., Opravil, S., Mechtler, K., Ponting, C.P., Allis, C.D., et al. 2000. Regulation of chromatin structure by sitespecific histone H3 methyltransferases. Nature 406: 593 599.

Reya, T., Morrison, S.J., Clarke, M.F., and Weissman, I.L. 2001. Stem cells, cancer, and cancer stem cells. Nature 414: 105 111.

Reynolds, P.A., Sigaroudinia, M., Zardo, G., Wilson, M.B., Benton, G.M., Miller, C.J., Hong, C., Fridlyand, J., Costello, J.F., and Tlsty, T.D. 2006. Tumor suppressor P16INK4A regulates polycomb-mediated DNA hypermethylation in human 
mammary epithelial cells. J. Biol. Chem. 281: 24790-24802.

Rhee, I., Jair, K.W., Yen, R.W., Lengauer, C., Herman, J.G., Kinzler, K.W., Vogelstein, B., Baylin, S.B., and Schuebel, K.E. 2000. CpG methylation is maintained in human cancer cells lacking DNMT1. Nature 404: 1003-1007.

Rhee, I., Bachman, K.E., Park, B.H., Jair, K.W., Yen, R.W., Schuebel, K.E., Cui, H., Feinberg, A.P., Lengauer, C., Kinzler, K.W., et al. 2002. DNMT1 and DNMT3b cooperate to silence genes in human cancer cells. Nature 416: 552-556.

Rice, J.C., Briggs, S.D., Ueberheide, B., Barber, C.M., Shabanowitz, J., Hunt, D.F., Shinkai, Y., and Allis, C.D. 2003. Histone methyltransferases direct different degrees of methylation to define distinct chromatin domains. Mol. Cell 12: 1591-1598.

Ringrose, L. and Paro, R. 2004. Epigenetic regulation of cellular memory by the Polycomb and Trithorax group proteins. Annu. Rev. Genet. 38: 413-443.

Robert, M.F., Morin, S., Beaulieu, N., Gauthier, F., Chute, I.C., Barsalou, A., and MacLeod, A.R. 2003. DNMT1 is required to maintain $\mathrm{CpG}$ methylation and aberrant gene silencing in human cancer cells. Nat. Genet. 33: 61-65.

Robertson, K.D. 2005. DNA methylation and human disease. Nat. Rev. Genet. 6: 597-610.

Robertson, K.D., Uzvolgyi, E., Liang, G., Talmadge, C., Sumegi, J., Gonzales, F.A., and Jones, P.A. 1999. The human DNA methyltransferases (DNMTs) 1, 3a and 3b: Coordinate mRNA expression in normal tissues and overexpression in tumors. Nucleic Acids Res. 27: 2291-2298.

Robertson, K.D., Ait-Si-Ali, S., Yokochi, T., Wade, P.A., Jones, P.L., and Wolffe, A.P. 2000. DNMT1 forms a complex with $\mathrm{rb}, \mathrm{E} 2 \mathrm{~F} 1$ and HDAC1 and represses transcription from E2Fresponsive promoters. Nat. Genet. 25: 338-342.

Rountree, M.R., Bachman, K.E., and Baylin, S.B. 2000. DNMT1 binds HDAC2 and a new co-repressor, DMAP1, to form a complex at replication foci. Nat. Genet. 25: 269-277.

Sakatani, T., Kaneda, A., Iacobuzio-Donahue, C.A., Carter, M.G., de Boom Witzel, S., Okano, H., Ko, M.S., Ohlsson, R., Longo, D.L., and Feinberg, A.P. 2005. Loss of imprinting of Igf2 alters intestinal maturation and tumorigenesis in mice. Science 307: 1976-1978.

Satoh, A., Toyota, M., Itoh, F., Sasaki, Y., Suzuki, H., Ogi, K., Kikuchi, T., Mita, H., Yamashita, T., Kojima, T., et al. 2003. Epigenetic inactivation of CHFR and sensitivity to microtubule inhibitors in gastric cancer. Cancer Res. 63: 8606-8613.

Schotta, G., Ebert, A., Krauss, V., Fischer, A., Hoffmann, J., Rea, S., Jenuwein, T., Dorn, R., and Reuter, G. 2002. Central role of Drosophila SU(VAR)3-9 in histone H3-K9 methylation and heterochromatic gene silencing. $E M B O \quad J$. 21: $1121-1131$

Schotta, G., Ebert, A., and Reuter, G. 2003. SU/VAR)3-9 is a conserved key function in heterochromatic gene silencing. Genetica 117: 149-158.

Schwartz, Y.B., Kahn, T.G., Dellino, G.I., and Pirrotta, V. 2004. Polycomb silencing mechanisms in Drosophila. Cold Spring Harb. Symp. Quant. Biol. 69: 301-308.

Seligson, D.B., Horvath, S., Shi, T., Yu, H., Tze, S., Grunstein, M., and Kurdistani, S.K. 2005. Global histone modification patterns predict risk of prostate cancer recurrence. Nature 435: $1262-1266$

Sharpless, N.E. and DePinho, R.A. 2002. p53: Good cop/bad cop. Cell 110: 9-12.

Shi, Y., Lan, F., Matson, C., Mulligan, P., Whetstine, J.R., Cole, P.A., Casero, R.A., and Shi, Y. 2004. Histone demethylation mediated by the nuclear amine oxidase homolog LSD1. Cell 119: 941-953.

Shi, Y.J., Matson, C., Lan, F., Iwase, S., Baba, T., and Shi, Y. 2005. Regulation of LSD1 histone demethylase activity by its associated factors. Mol. Cell 19: 857-864.

Silverman, L.R., Demakos, E.P., Peterson, B.L., Kornblith, A.B., Holland, J.C., Odchimar-Reissig, R., Stone, R.M., Nelson, D., Powell, B.L., DeCastro, C.M., et al. 2002. Randomized controlled trial of azacitidine in patients with the myelodysplastic syndrome: A study of the cancer and leukemia group B. J. Clin. Oncol. 20: 2429-2440.

Strahl, B.D. and Allis, C.D. 2000. The language of covalent histone modifications. Nature 403: 41-45.

Suka, N., Luo, K., and Grunstein, M. 2002. Sir2p and Sas2p opposingly regulate acetylation of yeast histone $\mathrm{H} 4$ lysine 16 and spreading of heterochromatin. Nat. Genet. 32: 378-383.

Surani, M.A. 1991. Genomic imprinting: Developmental significance and molecular mechanism. Curr. Opin. Genet. Dev. 1: 241-246.

Surani, M.A. 1993. Genomic imprinting. Silence of the genes. Nature 366: 302-303.

Suzuki, H., Gabrielson, E., Chen, W., Anbazhagan, R., van Engeland, M., Weijenberg, M.P., Herman, J.G., and Baylin, S.B. 2002. A genomic screen for genes upregulated by demethylation and histone deacetylase inhibition in human colorectal cancer. Nat. Genet. 31: 141-149.

Suzuki, H., Watkins, D.N., Jair, K.W., Schuebel, K.E., Markowitz, S.D., Chen, W.D., Pretlow, T.P., Yang, B., Akiyama, Y., Van Engeland, M., et al. 2004. Epigenetic inactivation of SFRP genes allows constitutive WNT signaling in colorectal cancer. Nat. Genet. 36: 417-422.

Suzuki, M., Sunaga, N., Shames, D.S., Toyooka, S., Gazdar, A.F., and Minna, J.D. 2004. RNA interference-mediated knockdown of DNA methyltransferase 1 leads to promoter demethylation and gene re-expression in human lung and breast cancer cells. Cancer Res. 64: 3137-3143.

Tamaru, H. and Selker, E.U. 2001. A histone H3 methyltransferase controls DNA methylation in Neurospora crassa. $\mathrm{Na}$ ture 414: 277-283.

Tamaru, H., Zhang, X., McMillen, D., Singh, P.B., Nakayama, J., Grewal, S.I., Allis, C.D., Cheng, X., and Selker, E.U. 2003 Trimethylated lysine 9 of histone $\mathrm{H} 3$ is a mark for DNA methylation in Neurospora crassa. Nat. Genet. 34: 75-79.

Tariq, M., Saze, H., Probst, A.V., Lichota, J., Habu, Y., and Paszkowski, J. 2003. Erasure of CpG methylation in Arabidopsis alters patterns of histone $\mathrm{H} 3$ methylation in heterochromatin. Proc. Nat1. Acad. Sci. 100: 8823-8827.

Ting, A.H., Jair, K.W., Suzuki, H., Yen, R.W., Baylin, S.B., and Schuebel, K.E. 2004. CpG island hypermethylation is maintained in human colorectal cancer cells after RNAi-mediated depletion of DNMT1. Nat. Genet. 36: 582-584.

Ting, A.H., Schuebel, K.E., Herman, J.G., and Baylin, S.B. 2005. Short double-stranded RNA induces transcriptional gene silencing in human cancer cells in the absence of DNA methylation. Nat. Genet. 37: 906-910.

Ting, A.H., Jair, K.W., Schuebel, K.E., and Baylin, S.B. 2006. Differential requirement for DNA methyltransferase 1 in maintaining human cancer cell gene promoter hypermethylation. Cancer Res. 66: 729-735.

Tissenbaum, H.A. and Guarente, L. 2001. Increased dosage of a sir-2 gene extends lifespan in Caenorhabditis elegans. $\mathrm{Na}$ ture 410: 227-230

Tsukada, Y., Fang, J., Erdjument-Bromage, H., Warren, M.E., Borchers, C.H., Tempst, P., and Zhang, Y. 2006. Histone demethylation by a family of JmjC domain-containing proteins. Nature 439: 811-816.

Tuck-Muller, C.M., Narayan, A., Tsien, F., Smeets, D.F., Sawyer, J., Fiala, E.S., Sohn, O.S., and Ehrlich, M. 2000. DNA hypomethylation and unusual chromosome instability in cell lines fromICF syndrome patients. Cytogenet. Cell 
Genet. 89: 121-128.

Ushijima, T. 2005. Detection and interpretation of altered methylation patterns in cancer cells. Nat. Rev. Cancer 5: 223-231.

Valenta, T., Lukas, J., Doubravska, L., Fafilek, B., and Korinek, V. 2006. HIC1 attenuates Wnt signaling by recruitment of TCF- 4 and $\beta$-catenin to the nuclear bodies. EMBO J. 25: 2326-2337.

Valk-Lingbeek, M.E., Bruggeman, S.W., and van Lohuizen, M. 2004. Stem cells and cancer; the polycomb connection. Cell 118: 409-418.

van 't Veer, L.J., Dai, H., van de Vijver, M.J., He, Y.D., Hart, A.A., Mao, M., Peterse, H.L., van der Kooy, K., Marton, M.J., Witteveen, A.T., et al. 2002. Gene expression profiling predicts clinical outcome of breast cancer. Nature 415: 530536.

Varambally, S., Dhanasekaran, S.M., Zhou, M., Barrette, T.R., Kumar-Sinha, C., Sanda, M.G., Ghosh, D., Pienta, K.J., Sewalt, R.G., Otte, A.P., et al. 2002. The polycomb group protein EZH2 is involved in progression of prostate cancer. $\mathrm{Na}$ ture 419: 624-629.

Vaziri, H., Dessain, S.K., Ng Eaton, E., Imai, S.I., Frye, R.A., Pandita, T.K., Guarente, L., and Weinberg, R.A. 2001. hSIR2(SIRT1) functions as an NAD-dependent p53 deacetylase. Cell 107: 149-159.

Vertino, P.M., Yen, R.W., Gao, J., and Baylin, S.B. 1996. De novo methylation of $\mathrm{CpG}$ island sequences in human fibroblasts overexpressing DNA (cytosine-5-)-methyltransferase. Mol. Cell. Biol. 16: 4555-4565.

Vire, E., Brenner, C., Deplus, R., Blanchon, L., Fraga, M., Didelot, C., Morey, L., Van Eynde, A., Bernard, D., Vanderwinden, J.M., et al. 2006. The Polycomb group protein EZH2 directly controls DNA methylation. Nature 439: 871-874.

Volpe, T.A., Kidner, C., Hall, I.M., Teng, G., Grewal, S.I., and Martienssen, R.A. 2002. Regulation of heterochromatic silencing and histone H3 lysine-9 methylation by RNAi. Science 297: 1833-1837.

Volpe, T., Schramke, V., Hamilton, G.L., White, S.A., Teng, G., Martienssen, R.A., and Allshire, R.C. 2003. RNA interference is required for normal centromere function in fission yeast. Chromosome Res. 11: 137-146.

Wagner, A., Barrows, A., Wijnen, J.T., van der Klift, H., Franken, P.F., Verkuijlen, P., Nakagawa, H., Geugien, M., JaghmohanChangur, S., Breukel, C., et al. 2003. Molecular analysis of hereditary nonpolyposis colorectal cancer in the United States: High mutation detection rate among clinically selected families and characterization of an American founder genomic deletion of the MSH2 gene. Am. J. Hum. Genet. 72: 1088-1100.

Wales, M.M., Biel, M.A., el Deiry, W., Nelkin, B.D., Issa, J.P., Cavenee, W.K., Kuerbitz, S.J., and Baylin, S.B. 1995. p53 activates expression of HIC-1, a new candidate tumour suppressor gene on 17p13.3. Nat. Med. 1: 570-577.

Wassenegger, M. and Pelissier, T. 1998. A model for RNA-mediated gene silencing in higher plants. Plant Mol. Biol. 37: 349-362.

Weisenberger, D.J., Siegmund, K.D., Campan, M., Young, J., Long, T.I., Faasse, M.A., Kang, G.H., Widschwendter, M., Weener, D., Buchanan, D., et al. 2006. CpG island methylator phenotype underlies sporadic microsatellite instability and is tightly associated with BRAF mutation in colorectal cancer. Nat. Genet. 38: 787-793.

Wu, J., Issa, J.P., Herman, J., Bassett Jr., D.E., Nelkin, B.D., and Baylin, S.B. 1993. Expression of an exogenous eukaryotic DNA methyltransferase gene induces transformation of NIH 3T3 cells. Proc. Natl. Acad. Sci. 90: 8891-8895.
Xin, Z., Tachibana, M., Guggiari, M., Heard, E., Shinkai, Y., and Wagstaff, J. 2003. Role of histone methyltransferase G9a in CpG methylation of the Prader-Willi syndrome imprinting center. J. Biol. Chem. 278: 14996-15000.

Xu, G.L., Bestor, T.H., Bourc'his, D., Hsieh, C.L., Tommerup, N., Bugge, M., Hulten, M., Qu, X., Russo, J.J., and ViegasPequignot, E. 1999. Chromosome instability and immunodeficiency syndrome caused by mutations in a DNA methyltransferase gene. Nature 402: 187-191.

Yamada, T., Fischle, W., Sugiyama, T., Allis, C.D., and Grewal, S.I. 2005. The nucleation and maintenance of heterochromatin by a histone deacetylase in fission yeast. Mol. Cell 20: $173-185$.

Yamane, K., Toumazou, C., Tsukada, Y., Erdjument-Bromage, H., Tempst, P., Wong, J., and Zhang, Y. 2006. JHDM2A, a JmjC-containing H3K9 demethylase, facilitates transcription activation by androgen receptor. Cell 125: 483-495.

Yamashita, K., Dai, T., Dai, Y., Yamamoto, F., and Perucho, M. 2003. Genetics supersedes epigenetics in colon cancer phenotype. Cancer Cell 4: 121-131.

Yan, L., Nass, S.J., Smith, D., Nelson, W.G., Herman, J.G., and Davidson, N.E. 2003. Specific inhibition of DNMT1 by antisense oligonucleotides induces re-expression of estrogen receptor- $\alpha$ (ER) in ER-negative human breast cancer cell lines. Cancer Biol. Ther. 2: 552-556.

Zollman, S., Godt, D., Prive, G.G., Couderc, J.L., and Laski, F.A. 1994. The BTB domain, found primarily in zinc finger proteins, defines an evolutionarily conserved family that includes several developmentally regulated genes in Drosophila. Proc. Natl. Acad. Sci. 91: 10717-10721. 


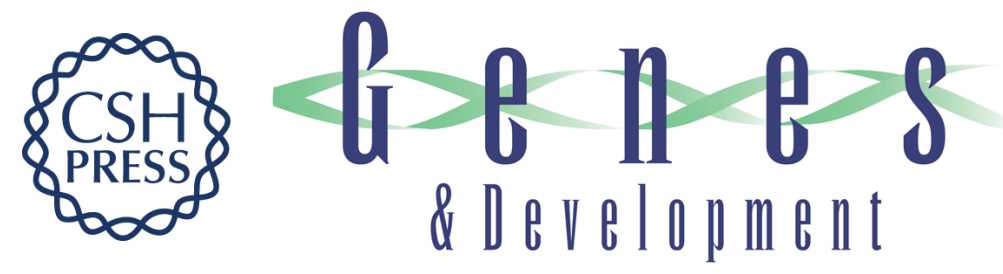

\section{The cancer epigenome--components and functional correlates}

Angela H. Ting, Kelly M. McGarvey and Stephen B. Baylin

Genes Dev. 2006, 20:

Access the most recent version at doi:10.1101/gad.1464906

References This article cites 232 articles, 82 of which can be accessed free at: http://genesdev.cshlp.org/content/20/23/3215.full.html\#ref-list-1

License

Email Alerting Receive free email alerts when new articles cite this article - sign up in the box at the top Service right corner of the article or click here.

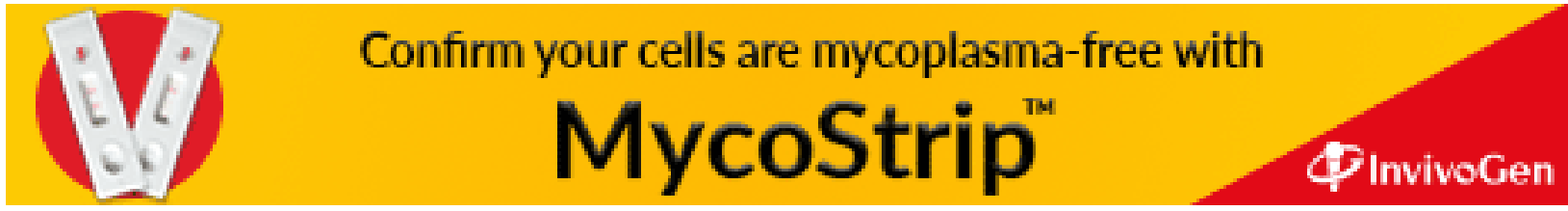

